\title{
Effect of Cryopreservation Method Supported With Biochemical Analyses in the Axillary Bud of Jewel Orchid, Ludisia Discolor
}

Hazirah Burkhan

Universiti Sains Malaysia

Kirutika Selva Rajan

Universiti Sains Malaysia

Suganthi Appalasamy

Universiti Malaysia Kelantan

Ranjetta Poobathy

Quest International University

Bee Lynn Chew

Universiti Sains Malaysia

Vanitha Mariappan

Universiti Kebangsaan Malaysia

Sreeramanan Subramaniam ( $\nabla$ sreeramanan@gmail.com )

Universiti Sains Malaysia

\section{Research Article}

Keywords: Axillary bud, Cryopreservation, Droplet-vitrification, Ludisia discolor, Orchid, Reactive oxygen species

Posted Date: November 29th, 2021

DOI: https://doi.org/10.21203/rs.3.rs-1061016/v1

License: (c) (i) This work is licensed under a Creative Commons Attribution 4.0 International License. Read Full License

Version of Record: A version of this preprint was published at Plants on March 25th, 2022. See the published version at https://doi.org/10.3390/plants11070879. 


\section{Abstract}

This study was conducted to investigate the potential of conserving an endangered terrestrial jewel orchid Ludisia discolorusing in vitro grown axillary buds. Excised segments of axillary buds (4 - $5 \mathrm{~mm}$ in length) were precultured on a modified Murashige and Skoog (MS) medium supplemented with $0.2 \mathrm{M}$ sucrose for $24 \mathrm{~h}$ and osmoprotected in a loading solution for $20 \mathrm{~min}$. Then, axillary buds were dehydrated in PVS2 solution for $10 \mathrm{~min}$ at $0^{\circ} \mathrm{C}$ and incubated in liquid nitrogen for $1 \mathrm{~h}$. Subsequently, axillary buds were rewarmed rapidly by dilution solution and transferred to a growth recovery medium supplemented with $0.05 \mu \mathrm{M}$ melatonin under in vitro conditions that led to an improved survival chance $(16.67 \%)$ for cryopreserved $L$. discolor. The abiotic stresses and the overproduction of reactive oxygen species (ROS) during cryopreservation stages may contribute to cryoinjuries and poor survival. The varied response towards stress was detected with significantly increased values recorded at certain cryopreservation stages, including proline activity at the dehydration stage $(5.51 \mu \mathrm{mol} / \mathrm{g})$, catalase at the preculture (85.64 $\mathrm{U} / \mathrm{g}$ ) and dehydration $(70.87 \mathrm{U} / \mathrm{g}$ ) stages, peroxidase at the rewarming stage $(565.37 \mathrm{U} / \mathrm{g})$ and ascorbate peroxidase during the loading stage $(12.19 \mathrm{U} / \mathrm{g})$. Hence, this first attempt to cryopreserved $L$. discolor indicates that future experimental designs could include exogenous antioxidants and different vitrification solutions to improve survival and regeneration.

\section{Highlights}

- First investigation on the possibility of cryopreserving jewel orchid, Ludisia discolor by dropletvitrification method.

- Low sucrose at short duration increased the survival of cryopreserved axillary buds.

- Low temperature with short incubation period enhanced the survival of cryopreserved axillary buds.

- Overall survival percentage of less than $30 \%$ suggests the possibility to cryopreserve L. discolor.

- Biochemical analyses were subjected with significant differences at different cryopreservation stages.

\section{Key Message}

Jewel orchid Ludisia discolor is amenable to long-term storage using droplet-vitrification by manipulating the preculture duration and concentration, the PVS2 treatment alongside antioxidant presence in the recovery stage.

\section{Introduction}

Orchidaceae is one of the most abundant and globally distributed flowering plant families (Christenhusz and Byng 2016), with some 972 species in 159 genera recorded in Peninsular Malaysia (Kiew et al. 2010; Go et al. 2015; Ong et al. 2017; Besi et al. 2020) of which at least 136 species were found in Penang Hill (Go et al. 2011). Ludisia belongs to a group of terrestrial orchids cultivated for their attractive ornamental 
leaves commonly referred to as 'Jewel Orchids' (Poobathy et al. 2019). These ground-dwellers found thriving on the damp forest floors are native to China and Southeast Asia (Govaerts et al. 2020) including Malaysia (Ong et al. 2017).

Many orchids are traded commercially for medicine, food, and as ornamental plants (Popova et al. 2016; Hinsley et al. 2018; Teoh 2019). Due to their symbiotic association with mycorrhizal fungi, specialized pollinators, and limited germination rates (Swarts and Dixon 2009; Zhang et al. 2018; Gale et al. 2019), most of the orchid species are narrowly distributed in specific habitats. They are steadily dwindling in their natural population through habitat loss and indiscriminate collection of wild orchids. A case study on orchid extinction in Malaysia was well documented by Go et al. (2020).

Maintenance of in vitro plants collection by repeated subcultures is labour-intensive, costly and the risks of contamination and somaclonal variation in orchid materials increase with time (Kulus and Zalewska 2014; Coelho et al. 2020). Such drawbacks have led to the development of safe and long-term conservation strategies through cryopreservation of organs and tissues that have made significant progress over the years (Popova et al. 2016; Reed 2017; Wang et al. 2020). Cryopreservation is the storage of biological materials at ultra-low temperature, typically liquid nitrogen (LN) at $-196^{\circ} \mathrm{C}$ (Sakai and Engelmann 2007). All metabolic activities such as respiration and cellular division of biological materials (including seeds, stems apices, axillary and apical buds, and cell suspensions) are halted at such temperatures. Thus, the risks of somaclonal variation or genetic changes are reduced, which in principle enables indefinite conservation (Benson 2008). In practice, biological materials of commercially important crops threatened plants, and plants with horticultural importance survived the storage durations in LN for as short as $1 \mathrm{hr}$ to $48 \mathrm{hrs}$ (Mikuła et al. 2011; Edesi et al. 2020) and as long as 1.5 to 28 years (Caswell and Kartha 2009; Mikuła et al. 2011; Volkova et al. 2015; Beulé et al. 2018; Ballesteros and Pence 2019).

Vitrification-based techniques constitute one of the contemporary methods in preserving orchids' biodiversity (Popova et al. 2016). Vitrification refers to a phase transition from liquid water to solid glass instead of lethal ice crystals, which formed within cells upon rapid cooling in LN temperatures (Engelmann 2011). During dehydration, as the amorphous glass occupies space in a cell, it may hamper cell deterioration, solute concentration, and pH alteration (Benson 2008) while maintaining the high cell viscosity. Droplet-vitrification is one of the recent techniques being adopted and continuously refined in orchid cryopreservation (González-Arnao et al. 2020) as it combines both rapid cooling and warming strategy with a mixture of high solute concentration of cryoprotectants (namely dimethyl sulfoxide [DMSO], ethylene glycol, and sugar such as glucose or sucrose) to inhibit ice nucleation and growth (Panis et al. 2005).

Vitrification-based techniques inflict various stressful conditions on the plant materials resulting in growth impairment after rewarming. The stresses that occurred included excision of plant materials, osmotic injury and dehydration following treatment with highly concentrated cryoprotectants, and freezing injury from sudden temperature changes. Consequently, oxidative damage occurs due to the 
increased accumulation of reactive oxygen species (ROS) (Uchendu et al. 2010; Antony et al. 2019). ROS including superoxide radical $\left(\mathrm{O}_{2}^{-}\right)$, hydrogen peroxide $\left(\mathrm{H}_{2} \mathrm{O}_{2}\right)$, hydroxyl radical $\left(\mathrm{OH}^{-}\right)$, and singlet oxygen $\left({ }^{1} \mathrm{O}_{2}\right)$ is produced in chloroplasts, mitochondria, and peroxisomes (Suzuki et al. 2012). Under typical growth environments, there is an equilibrium between the production of ROS and protective antioxidants. However, overproduction of ROS will exhaust the capacity of the antioxidants in cellular repair processes, and biological deterioration can occur (Suzuki and Mittler 2006). Hence, various precautions are taken to induce cell tolerance and regrowth ability such as the inclusion of sugar in preculture media (Bissati et al. 2020), the mixture of cryoprotectants, exposure duration, and temperature (Elliott et al. 2017), the alteration in regrowth media with the addition of supplements (Uchendu et al. 2014; Diengdoh et al. 2019) and light condition (Edesi et al. 2017).

However, much uncertainty still exists about the harmful effects experienced by a cryopreserved cell or tissue, whether the damage happens during the cooling-rewarming period or an accumulation of damaging events that manifest after several hours to days. An analytical tool such as biochemical analyses is efficient to provide insights into the effect of cryopreservation at the cellular level. Proline, catalase (CAT), peroxidase (POX), and ascorbate peroxidase (APX), which are part of the protective antioxidants that scavenge the excess ROS in plants, can be utilized as biomarkers indicating plant defense mechanisms in response to various oxidative stress encountered during cryopreservation stages (Poobathy et al. 2013; Antony et al. 2019).

The current study aimed to examine the possible effects of cryopreserving $L$. discolor orchid by dropletvitrification technique, supported with biochemical analyses.

\section{Materials And Methods}

Plant material and propagation of cultures

In vitro stock culture of L. discolor (Fig. 1a) was obtained from Laboratory 101, Industrial Biotechnology Research Laboratory, School of Biological Sciences, Universiti Sains Malaysia.

Nodal segments of $L$. discolor (Fig. $1 \mathrm{~b}$ ) were aseptically cultured to initiate axillary buds for cryopreservation study. Based on the preliminary tests, half-strength semi-solid Murashige and Skoog (1962) medium (MS) fortified with $0.2 \%(\mathrm{w} / \mathrm{v})$ activated charcoal, $8 \%(\mathrm{w} / \mathrm{v})$ Mas banana cultivar homogenate, $3.5 \mathrm{~g} / \mathrm{L}$ Gelrite ${ }^{\mathrm{TM}}, 1.0 \mathrm{mg} / \mathrm{L} 1$-naphthaleneacetic acid (NAA), and $0.1 \mathrm{mg} / \mathrm{L}$ thidiazuron (TDZ) was found effective to propagate $L$. discolor. The cultures were maintained at a temperature of 24 $\pm 2{ }^{\circ} \mathrm{C}$ with a relative humidity of $51 \pm 2 \%$ under cool white light-emitting diode (LED) $(17 \mu \mathrm{mol} / \mathrm{s})$ with $16 / 8$ hours of light/dark regime (standard growth condition). Micropropagation of the in vitro stock cultures were performed at a 12-week interval.

Media preparation 
All media used in the study were supplemented with a half-strength MS medium. The preculture media were supplemented with sucrose concentrations $(0.0,0.2,0.4$, and $0.6 \mathrm{M})$, while the loading solution contained $0.4 \mathrm{M}$ sucrose and $2.0 \mathrm{M}$ glycerol (J.T. Baker, USA). The PVS2 consisted of $30 \%(\mathrm{w} / \mathrm{v})$ glycerol, 15\% (w/v) ethylene glycol (Friendemann Schmidt, USA), 15\% (w/v) DMSO (Qrec, Malaysia) and $0.4 \mathrm{M}$ sucrose (Sakai et al. 1990), and the unloading solution contained 1.2 M sucrose. The growth recovery media were half-strength semi-solid MS enriched with $3 \%$ sucrose and $2.75 \mathrm{~g} / \mathrm{L}$ Gelrite ${ }^{\mathrm{TM}}$ supplemented with melatonin $(0,0.05,0.10,0.50$ and $1.0 \mu \mathrm{M})$ (Sigma-Aldrich, USA). The pH was all adjusted to 5.75 .8 by adding $1 \mathrm{~N}$ Sodium hydroxide $(\mathrm{NaOH})$ or $1 \mathrm{~N}$ Hydrochloric acid $(\mathrm{HCl})$ before autoclaving at $121^{\circ} \mathrm{C}$ for 15 min (Tomy High-Pressure Steam Sterilizer ES-315, Japan). All chemicals are manufactured from Duchefa Biochemie (Netherlands), unless specified otherwise.

Cryopreservation method

Axillary buds of $L$. discolor ( $4-5 \mathrm{~mm}$ ) were used as a starting material for cryopreservation using the droplet-vitrification method adapted from Khor et al. (2017).

The excised axillary buds were precultured in a half-strength semi-solid MS medium supplemented with sucrose $(0,0.2,0.4$, and $0.6 \mathrm{M})$ at various durations $(24,48,72$, and $120 \mathrm{~h})$. Next, the axillary buds were osmoprotected with $1.5 \mathrm{~mL}$ of loading solution for $20 \mathrm{~min}$ at $25^{\circ} \mathrm{C}$, followed by dehydration in PVS2 solution for $5,10,20$, and $30 \mathrm{~min}$ (at 0 and $25^{\circ} \mathrm{C}$ ). Five minutes before the end of the dehydration treatment, a droplet of the PVS2 solution was placed on an aluminum foil strip $(1 \times 3 \mathrm{~cm})$ before direct immersion in LN (MVE lab 20, MVE Bio-Medical Division, Chart Industries, Inc., USA). One axillary bud was placed in each of the PVS2 droplets. The aluminum foils (secured in a cryotube) were then directly plunged in LN and maintained for at least $1 \mathrm{hr}$. LN storage step was omitted for non-cryopreserved axillary buds (negative control). Next, the aluminum strips were removed from the cryotube and quickly rewarmed in $10 \mathrm{~mL}$ of unloading solution. The solution is swirled for a few seconds until the axillary buds detached from the strips and held for another $20 \mathrm{~min}$ at $25^{\circ} \mathrm{C}$.

Both control and cryopreserved axillary buds were subjected to the unloading solution. Following this, the axillary buds were transferred onto sterile filter paper affixed on half-strength MS regrowth media and incubated in the dark overnight. Next, the axillary buds were transferred onto a fresh regrowth media, excluding the filter paper. Regrowth of both control and cryopreserved axillary buds was conducted for three weeks at $24 \pm 2{ }^{\circ} \mathrm{C}$. For the first week, the axillary buds were kept in complete darkness followed by one week under dim light conditions ( $3 \mu \mathrm{mol} / \mathrm{s})$ and subsequently incubated under standard growth conditions of 16 -hours photoperiod.

2,3,5-triphenyltetrazolium chloride (TTC) assay

The survival of both control and cryopreserved axillary buds was assessed three weeks after the cryopreservation protocol using TTC spectrophotometric analysis at $490 \mathrm{~nm}$ (U-1900 UV-VIS Spectrophotometer 200V, 3J0-0003, Hitachi, Japan). The TTC assay method was adapted from prescribed protocols (Steponkus and Lanphear 1967; Harding and Benson 1995) with slight 
modifications. The axillary buds from the regrowth media were transferred into universal bottles containing $2 \mathrm{~mL}$ of TTC solution: 0.6\% (w/v) TTC (Sigma-Aldrich, USA) and 0.05\% (v/v) Tween 80 (R\&M Chemicals, UK) in a buffer solution consisting of $0.05 \mathrm{M}$ of both disodium hydrogen phosphate dihydrate $\left(\mathrm{Na}_{2} \mathrm{HPO}_{4} \cdot 2 \mathrm{H}_{2} \mathrm{O}\right)$ and potassium dihydrogen phosphate $\left(\mathrm{KH}_{2} \mathrm{PO}_{4}\right)(\mathrm{R} \& \mathrm{M}$ Chemicals, $\mathrm{UK})$ at $\mathrm{pH} 7.4$ (Verleysen et al. 2004). The axillary buds were incubated in the dark for 24 hours.

After the incubation time, axillary buds were subjected to visual inspection of the surface stained with formazan using a stereoscopic dissecting microscope (Olympus, Japan), with any red-stained evidence axillary buds confirming the existence of viable cells as evaluated by Poobathy et al. (2013).

For the spectrophotometric-TTC assay, the residual TTC solution in the universal bottle was removed, and the axillary buds were rinsed three times with $3.5 \mathrm{~mL}$ of distilled water. Then, the formazan color present in the axillary buds was extracted with $7 \mathrm{~mL}$ of $95 \%$ ethanol (HmbG Chemicals, Germany) in a water bath at $80{ }^{\circ} \mathrm{C}$ for one hour. The extract was cooled and a spectrophotometer analyzed the reading absorbance of formazan color at $490 \mathrm{~nm}$ wavelength against a blank of $95 \%$ ethanol.

Biochemical analyses

Axillary buds were collected for enzyme extraction at various cryopreservation stages adapted from Mubbarakh et al. (2019) as follows:

1. Axillary buds excised from in vitro plants (control);

2. Preculture on medium containing $0.2 \mathrm{M}$ sucrose;

3. Osmoprotection by loading solution;

4. Dehydration with PVS2 for 10 min;

5. Rapid cooling and rewarming;

6. Recovery after 1 day on growth medium with $0.05 \mu \mathrm{M}$ melatonin (Recovery 1 );

7. Recovery after 3 weeks on growth medium with $0.05 \mu \mathrm{M}$ melatonin (Recovery 2 )

Proline analysis

The proline content was determined according to Bates et al. (1973). About $100 \mathrm{mg}$ of axillary buds was macerated using mortar and pestle and placed in a $25 \mathrm{~mL}$ test tube. Following that, $15 \mathrm{~mL}$ of $80 \%(\mathrm{v} / \mathrm{v})$ ethanol was added into the test tube and was incubated at $60^{\circ} \mathrm{C}$ water bath for $30 \mathrm{~min}$. The extract was filtered, and proline content $(\mu \mathrm{mol} / \mathrm{g})$ was measured with acid ninhydrin solution at $A_{520 \mathrm{~nm}}$ to obtain the absorbance reading and data was compared with proline standard curve.

Total soluble protein content

The Bradford method (Bradford 1976) was used to determine the protein content of the collected axillary buds. Bradford reagent was prepared by diluting Coomasie Brilliant Blue G-250 (Amresco, USA), 95\% (v/v) ethanol, and 85\% phosphoric acid (JT Baker, USA) with distilled water. The protein reagent was filtered to 
eliminate impurities until the solution turned brown. The solution was maintained in an amber bottle and refrigerated at $4{ }^{\circ} \mathrm{C}$.

Axillary buds with the weight of $100 \mathrm{mg}$ were ground in an iced cold mortar and homogenized with 0.6 $\mathrm{mL}$ of enzyme extraction buffer solution. Enzyme extraction buffer solution was made of $100 \mathrm{mM}$ potassium phosphate buffer ( $\mathrm{pH} 7.8), 2 \mathrm{mM}$ ethylenediaminetetraacetic acid and $2 \%(\mathrm{w} / \mathrm{v})$ polyvinylpyrrolidone (Monnet et al. 2006). The mixture was centrifuged at $15000 \mathrm{xg}$ for 20 minutes (Gyrozen, Model 1524). The resulting supernatant was stored overnight under $-40^{\circ} \mathrm{C}$ freezer.

The extract solution with a volume of $0.1 \mathrm{~mL}$ was transferred into $1 \mathrm{~mL}$ of Bradford reagent and vortexed. Bradford reagent was filtered with $0.45-\mu \mathrm{m}$ syringe filter prior to adding with extract solution. Soluble protein concentrations $(\mu \mathrm{g} / \mathrm{mL})$ were taken at $A_{595 \mathrm{~nm}}$ and compared with the standard bovine serum albumin (BSA).

Catalase (CAT) assay

The CAT enzyme activity was analyzed according to Sánchez-Rojo et al. (2015). The protein extract was obtained by homogenizing the chopped axillary buds $(100 \mathrm{mg})$ and an enzyme extraction buffer solution. The reaction mixture contained $30 \mu \mathrm{L}$ protein extract, $50 \mathrm{mM}$ potassium phosphate buffer $(\mathrm{pH} 7.0)$, and an addition of $30 \mathrm{mM} \mathrm{H}_{2} \mathrm{O}_{2}$ (R\&M Chemicals, $\mathrm{UK}$ ) to initiate the reaction. The decomposition of $\mathrm{H}_{2} \mathrm{O}_{2}$ was analyzed, and the absorbance was recorded at $A_{240} \mathrm{~nm}$ for $3 \mathrm{~min}$. The calculation for the enzyme activity in U/g was performed according to the formula derived from Flocco and Giulietti (2007), as demonstrated by Poobathy et al. (2013).

Peroxidase (POX) assay

The POX assay was evaluated following the protocol based on Sánchez-Rojo et al. (2015) and Antony et al. (2019). The protein extract was obtained by grinding $100 \mathrm{mg}$ of axillary buds in an iced cold mortar and homogenized with an enzyme extraction buffer solution. The total reaction mixture of $3 \mathrm{~mL}$ contained $50 \mathrm{mM}$ sodium phosphate ( $\mathrm{pH} 7.0$ ), $7.2 \mathrm{mM}$ guaiacol, $6.86 \mathrm{mM} \mathrm{H}_{2} \mathrm{O}_{2}$ and was initiated by 30 $\mu \mathrm{L}$ of protein extract. The reaction progress was measured by the increment in absorbance at $A_{470 \mathrm{~nm}}$ for 3 min. The enzyme activity (U/g) was calculated according to Flocco and Giulietti (2007).

Ascorbate peroxidase (APX) assay

The APX enzyme activity was adapted from Elavarthi and Martin (2010) and Rahmah et al. (2015). Axillary buds with a weight of $100 \mathrm{mg}$ were ground using a pre-cooled mortar and homogenized with an enzyme extraction buffer solution. The $3 \mathrm{~mL}$ assay mixture contained $50 \mathrm{mM}$ potassium phosphate $(\mathrm{pH}$ 7.0), $0.5 \mathrm{mM}$ ascorbic acid (Sigma-Aldrich, USA), and $30 \mu \mathrm{L}$ of protein extract. The reaction was initiated with the addition of $0.5 \mathrm{mM} \mathrm{H}_{2} \mathrm{O}_{2}$ and subsequently monitored at $\mathrm{A}_{290 \mathrm{~nm}}$ for $3 \mathrm{~min}$. The ascorbate peroxidase activity $(\mathrm{U} / \mathrm{g})$ calculation was based on Flocco and Giulietti (2007). 
The cryopreservation treatments consist of six replicates exposed to $L N(+L N)$ and six replicates without exposure to $L N(-L N)$, each containing five axillary buds. Experiments were performed according to a randomized complete block design. Each biochemical analysis is composed of six replicates with each containing enzyme extraction of $100 \pm 5 \mathrm{mg}$ of axillary buds per treatment. Means were analyzed by oneway analysis of variance (ANOVA) followed with Duncan Multiple Range Test (DMRT) with the probability value set at 0.05 using SPSS version 25 . The results were expressed as means \pm SE (standard error).

\section{Results}

Cryopreservation by droplet-vitrification protocol

In this study, the feasibility of cryopreserving axillary buds of $L$. discolor based on the effect of pretreatment with sucrose (concentration and duration), dehydration (duration and temperature), and the presence of antioxidants in growth recovery was investigated based on the absorbance reading and percentage of survival.

The survival percentage for cryopreserved axillary buds ranged from $10 \%$ to $26.67 \%$ with axillary buds precultured in a $0.2 \mathrm{M}$ sucrose showing the highest survivability with a significant difference in the absorbance value $\left(A_{490 \mathrm{~nm}}: 0.168\right)$. By contrast, increasing sucrose concentration to 0.4 and $0.6 \mathrm{M}$ resulted in $13 \%$ and $10 \%$ reduced growth, respectively (Fig. 2a). A similar trend was observed on noncryopreserved axillary buds, decreasing the survivability of $33.33 \%\left(A_{490 \mathrm{~nm}}: 0.038\right)$ when precultured in $0.6 \mathrm{M}$ sucrose (Fig. 2b). Gradually increasing the duration of preculture (24 $120 \mathrm{hr}$ ) with $0.2 \mathrm{M}$ sucrose was evaluated. As recorded in Fig. 2, the survival percentage of $L$. discolor decreased sharply to $3.33 \%$, indicating prolonged exposure to sucrose negatively affected the survival of axillary buds. The noncryopreserved axillary buds also showed the same pattern of viability. Axillary buds of $L$. discolor showed sensitivity towards sucrose.

Survival of axillary buds after dehydration with PVS2 for different durations at 0 and $25^{\circ} \mathrm{C}$ was depicted in Fig. 4. PVS2 incubated at $0^{\circ} \mathrm{C}$ was associated with higher axillary buds' survival compared to PVS2 set at $25^{\circ} \mathrm{C}$. Cryopreserved axillary buds exposed to PVS2 for up to $10 \mathrm{~min}$ at $0{ }^{\circ} \mathrm{C}$ resulted in an increase of survival at $20 \%\left(\mathrm{~A}_{490 \mathrm{~nm}}: 0.157\right)$ with a significant reduction when incubated at $25^{\circ} \mathrm{C}$ (Fig. $\left.4 \mathrm{a}\right)$. As exposure periods were prolonged to $30 \mathrm{~min}$ for both temperatures, the survival of axillary buds declined significantly. Fig. 4b illustrated the varied response for both cryopreserved and non-cryopreserved axillary buds at $0{ }^{\circ} \mathrm{C}$. Survival gradually increased from 43.33\% (5 $\mathrm{min}$ ) to $46.67 \%$ (10 $\mathrm{min}$ ) before a decrease of $10 \%$ when the non-cryopreserved axillary buds were exposed to PVS2 at $0{ }^{\circ} \mathrm{C}$. Dehydration with PVS2 at 0 ${ }^{\circ} \mathrm{C}$ for 10 min was chosen for the subsequent experiment.

The TTC absorbance values obtained from extracts of both cryopreserved $\left(A_{490 \mathrm{~nm}}: 0.157\right)$ and noncryopreserved $\left(A_{490 \mathrm{~nm}}: 0.187\right)$ axillary buds were significantly different with the addition of $0.05 \mu \mathrm{M}$ 
melatonin in growth recovery media (Fig. 5). Although no significant difference in survival of cryopreserved axillary buds was observed (Fig. 5a), a growth recovery media fortified with $0.05 \mu \mathrm{M}$ melatonin improved the chances of survival to $16.67 \%$ compared to $1.0 \mu \mathrm{M}$ melatonin $(6.67 \%)$. Comparably, better survival of non-cryopreserved meristems was recorded between $30 \%$ to $40 \%$ (Fig. 5 b).

Biochemical analyses during cryopreservation

Different cryopreservation stages significantly affected the proline accumulation, total soluble protein, and enzyme activities (catalase, peroxidase, and ascorbate peroxidase) of treated axillary meristems of $L$. discolor. Fig. 6 revealed a gradual increase of proline content which reached a peak during the dehydration stage $(5.51 \mu \mathrm{mol} / \mathrm{g})$ before a slight reduction of $40 \%$ after immersion in LN and rewarming. After 3 weeks in the growth recovery media (R2), the proline content was steadily reduced to 4.21 $\mu \mathrm{mol} / \mathrm{g}$.

All stages in cryopreservation resulted in significant differences ranging from 11.88 to $54.95 \mu \mathrm{g} / \mathrm{mL}$. Fig. 7 revealed that stock culture contained the highest soluble protein content before continuing to drop following the early stage of cryopreservation (preculture, loading, and dehydration). After storage in LN for an hour and exposure to unloading solution, the soluble protein content sharply increased to 38.04 $\mu \mathrm{g} / \mathrm{mL}$ before further declining in the recovery stage.

Figs. 8 to 10 showed the enzyme activities involved in protecting the cryopreserved axillary buds from injuries due to stress accumulated in each cryopreservation stage. The catalase activities peaked at the preculture $(85.64 \mathrm{U} / \mathrm{g})$ stage before a decrease during osmoprotection in the loading stage (Fig. 8). The catalase activities elevated in dehydration before gradually declined after incubation in LN with the lowest value of $8.43 \mathrm{U} / \mathrm{g}$.

Fig. 9 demonstrated fluctuated peroxidase activities. A significant increase between stock culture and preculture was observed before a slight decline during the dehydration stage. Then, the peroxidase activities peaked at $565.37 \mathrm{U} / \mathrm{g}$ after $\mathrm{LN}$ exposure, followed by a steep drop during the recovery stage (R1).

The ascorbate peroxidase activities rose during the early stages of cryopreservation, with the highest value observed before the $\mathrm{LN}$ incubation $(12.19 \mathrm{U} / \mathrm{g}$ ) (Fig. 10). Afterward, the enzyme activities further decreased with no significant differences observed between the stock culture and when axillary buds were subjected for a day in a growth recovery media (R1). R2 recorded the lowest enzyme activities at $1.56 \mathrm{U} / \mathrm{g}$.

\section{Discussion}

\section{Cryopreservation by droplet-vitrification protocol}

In this study, L. discolor, an endangered orchid species in Southeast Asia is amenable to long-term conservation by droplet-vitrification protocol. 
Cryopreservation protocol for $L$. discolor including its genus, has not been documented before. However, many orchid species are economically important and renowned for their medicinal, ornamental, and cultural values. Therefore, several cryopreservation protocols including desiccation, preculturedesiccation, encapsulation-dehydration, vitrification, and droplet-vitrification have been developed for several species in this family (Rajasegar et al. 2015; Bustam et al. 2016; Popova et al. 2016; Popova and Kim 2019; Rittirat et al. 2019). Notably, droplet-vitrification is one of the recent techniques being adopted and continuously refined in orchid cryopreservation (González-Arnao et al. 2020). Success in this method requires optimizing various parameters such as preculture (or not) on a sugar-enriched medium before incubating in a series of vitrification solutions that offers the advantage of rapid cooling and rewarming with a mixture of solute concentrations (Panis et al. 2020). These prerequisites are critical to increasing the dehydration and freezing tolerance of cryopreserved plants to be revived and propagated as a whole plant.

Sucrose preculture proved to be an essential step in enhancing $L$. discolor axillary buds' dehydration tolerance against subsequent cryo-treatment. The present findings highlighted the highest survival rate was achieved when axillary buds were precultured for $24 \mathrm{~h}$ in a $0.2 \mathrm{M}$ sucrose before cryopreservation. By contrast, a progressive increase of sucrose concentration (beyond $0.2 \mathrm{M}$ ) and prolonged exposure resulted in a low survival rate. This indicates a possibility of sucrose over-accumulation in the cytoplasm, causing an imbalance in the cellular state of cryopreserved explant and causing excessive dehydration and toxicity (Chua and Normah 2011). This is consistent with Brassidium Shooting Star orchid, whereby elevated sucrose concentration beyond $0.25 \mathrm{M}$ negatively affected the viability of cryopreserved PLBs (Mubbarakh et al. 2014). In cryopreserving protocorm-like bodies (PLBs) of Cymbidium Twilight Moon 'Day Light', sucrose at low concentration was found to be exceptional compared to the other osmoticum type, including different concentrations of mannose, polyethylene glycol (PEG-6000), and DMSO (Teixeira da Silva 2013). For Vanilla planifolia, apices treated with $0.3 \mathrm{M}$ sucrose for 1 day resulted in $30 \%$ of survival (Gonzalez-Arnao et al., 2009). In contrast, PLBs of Aranda Broga Blue required 0.2 M sucrose for 3 days (Khor et al. 2017). However, in 2016, collected findings (Popova et al. 2016) concluded that most orchids favored preculturing at $0.4-0.75 \mathrm{M}$ for 1 to 2 days including Pleione bulbocodioides (Cheng et al. 2020) and orchid hybrids of Brassidium Fly Away (Rajasegar et al. 2015) and Dendrobium Bobby Messina (Antony et al. 2011). For Cymbidium eburneum and C. hookeranium, exposure to $0.7 \mathrm{M}$ sucrose was only required for $20 \mathrm{~h}$ (Gogoi et al. 2013). Similarly, increased viability was recorded for orchid hybrid Ascocenda for sucrose treatment at $0.5 \mathrm{M}$ for $18 \mathrm{~h}$. Overall, existing literature agreed with the general notion that genotypic variations contribute to the varying survival rate due to sample heterogeneity. Thus, optimizing the preculture condition is critical for a successful cryopreservation protocol.

Interactions in the sugar membrane are postulated to be responsible for preserving cell integrity during dehydration and freezing. According to Stachura et al. (2019), the water replacement hypothesis occurred where the sucrose molecules interact with the bilayer phospholipid headgroups at low sucrose concentrations with high water content. These interactions and the network of hydrogen bonds with water molecules reinforce the stability of proteins and membrane bilayer during dehydration. This is consistent with several reports, including Kim et al. (2009), that reiterates sucrose aids as an osmotic 
buffer by replacing the water molecules during desiccation, thus facilitating subsequent treatment involving highly concentrated vitrification solutions.

Duration and temperature of PVS2 influenced the survival of cryopreserved axillary buds of $L$. discolor. PVS2 contains a mixture of vitrification solutions including glycerol, ethylene glycol, and DMSO that supports the liquid water to glass transition during rapid cooling in ultra-low temperature of LN (Sakai et al. 2008). With adequate exposure, these concentrated solutes can dehydrate, penetrate and induce adaptation towards freezing within the cryopreserved explant (Elliott et al. 2017). The temperature and length of application can influence the effectiveness, toxicity, and permeability of vitrification solutions. Consequently, these considerations may need to be evaluated on a case-by-case basis (Benson and Harding 2012). Present work substantiates previous findings in the literature whereby overexposure to vitrification solutions in an elevated temperature is associated with lower explants survival (Chua and Normah 2011; Mohanty et al. 2012; Mohanty et al. 2013). With Dactylorhiza fuchsii protocorms, $1 \mathrm{~h}$ of PVS2 treatment at $0{ }^{\circ} \mathrm{C}$ was necessary to stimulate growth (Nikishina et al. 2007). Incubation time and temperature for PVS2 usually differ with plant species as recorded in previous literature. Within Cymbidium species, varied responses were documented when vitrification technique was employed on different explants such as PLBs of $C$. finlaysonianum and Cymbidium Twilight Moon 'Day Light' endured well in 60 min and 80 min of PVS2 respectively, on ice, whereas optimum durations were documented for seeds to be $30 \mathrm{~min}$ for $C$. finlaysonianum and $60 \mathrm{~min}$ for $C$. goeringii and $C$. macrorhizon (Hirano et al. 2011; Teixeira da Silva 2013; Rittirat et al. 2019). By contrast, increased temperature is suitable for cryopreserved orchids to be sufficiently dehydrated in Dendrobium cruentum, D. signatum and Paphiopedilum niveum (Chaireok et al. 2016; Jitsopakul et al. 2019; Prasongsom et al. 2020; Soonthornkalump et al. 2020).

According to data presented by Volk et al. (2014), PVS2 treatment removes cellular water from tissues, thus minimizing the ice crystal formation. A published electron microscopy study of freeze-fractured and freeze-substitution of hydrated Acer saccharinum axes revealed that intracellular ice crystal formation was inevitable during freezing (Wesley-Smith et al. 2014). However, the cryopreserved explants managed to survive due to the rapid cooling rate $\left(70-300^{\circ} \mathrm{Cs}^{-1}\right)$ that limited the ice crystals' size and density (small; 2 - $4 \mathrm{~mm}$ and $10-20$ crystals $\mu \mathrm{m}^{-2}$ ) which appeared in the cytoplasm. The cooling rate on aluminum foils (droplet-vitrification), which is around $130^{\circ} \mathrm{Cs}^{-1}$ is faster than that on plastic cryovials (basic vitrification) of about $6{ }^{\circ} \mathrm{Cs}^{1}$ (Towill and Bonnart 2003). These facilitate a rapid transition to a meta-stable glass before nucleation and growth of ice crystals. The cooling rate and the optimum exposure to vitrification solutions will enhance the chances of survival after cryopreservation.

Abiotic stressors during cryopreservation (explant excision, osmotic injury, tissue dehydration, and temperature changes) promote an overproduction of reactive oxygen species (ROS) that causes oxidative damage (Uchendu et al. 2010). Moderate ROS production is necessary for secondary signaling molecules (Kai and Iba 2014). However, under stressed conditions, Møller et al. (2007) elaborated that ROS such as ${ }^{1} \mathrm{O}_{2}, \mathrm{O}_{2}{ }^{-}, \mathrm{H}_{2} \mathrm{O}_{2}$, and $\mathrm{OH}^{-}$can severely damage the membrane structures and other cell components by 
incorrect timing of programmed cell death. Scavenging these surplus radicals may achieve tolerance to such harmful effects (Halder et al. 2018). Published reports have employed antioxidants such as ascorbic acid, glutathione, and melatonin to directly remove the ROS and protect cellular functions, thus improving the chances of survival (Uchendu et al. 2013; Uchendu et al. 2014; Diengdoh et al. 2019; Mubbarakh et al. 2019; Khor et al. 2020; Soonthornkalump et al. 2020). Present findings showed that melatonin-supplemented during the recovery stage did not accelerate the growth of cryopreserved axillary buds of $L$. discolor (Fig. 1C). It is speculated that exogenous antioxidant interrupts the natural defense mechanism present in plants, thereby reducing the ability of the antioxidant to function resulting in only $16.67 \%$ of survivability for cryopreserved axillary buds and $40 \%$ for non-cryopreserved control axillary buds.

\section{Biochemical analyses during cryopreservation}

Biochemical analyses were performed as an indication of oxidative stress encountered during cryopreservation. In the present work, proline contents significantly increased during the early stages of cryopreservation and peaked during the dehydration stage before being reduced after $L N$ exposure. This signified the stressful dehydration conditions resulted in an overproduction of proline in cryopreserved axillary buds. Similarly, cryopreserved Dendrobium Sabin Blue exhibited the highest proline level after dehydration with PVS2 treatment (Antony et al. 2019). According to several studies, amino acid such as proline occurs typically in the cytoplasm and contributes to stress tolerance by behaving as a molecular chaperon that maintains the membrane integrity, alters cell osmotic pressure, and remove ROS (Hayat et al. 2012; Soshinkova et al. 2013; Dar et al. 2016).

Fluctuated outcomes were observed in the total soluble protein and all antioxidant enzyme activities (CAT, POX, and APX) involved in protecting cryopreserved axillary buds of $L$. discolor from injuries to stress accumulated in each cryopreservation stage. Drastic reduction of total soluble protein was observed during the recovery stage after storage in $L N$, indicating protein degradation due to high ROS production. On the other hand, cryopreserved axillary buds enhanced stress tolerance by increasing the synthesis of enzymatic antioxidants: CAT and APX (initial stages of cryopreservation) and POX (immediately after LN exposure followed with rewarming) that breaks down and remove the excess free radicals. The increased expression of antioxidants among the critical stages of cryopreservation may be due to the high production of $\mathrm{H}_{2} \mathrm{O}_{2}$, which in return triggers antioxidant activities as ROS scavengers (Antony et al. 2019; Vianna et al. 2019). However, the reduced expressions of antioxidant enzyme activities reflected the cryopreserved explants' inability to combat the accumulation of ROS, which in return led to the poor survival of explants and was associated with tissue browning reported by Rahmah et al. (2015).

\section{Conclusion}

Challenges remain regarding the slow growth of this jewel orchid. Nevertheless, the present findings indicate that cryopreservation using the droplet-vitrification technique can conserve the endangered wild orchid $L$. discolor using axillary buds. While low, the overall survival percentage of less than $30 \%$ 
suggests the possibility to cryopreserve $L$. discolor with careful planning and testing to ensure regeneration. Biochemical profiling as a stress indicator shows that accumulated abiotic stress correlates with elevated ROS production and resulted in cryodamage. Further investigations, including optimization of different vitrification solutions and incubation period and the application of antioxidants at various stages of cryopreservation, are warranted to improve this protocol and stimulate the regrowth of cryopreserved axillary buds. Histological approaches can also be considered to monitor the extent of cellular injuries inflicted during each cryopreservation stage.

\section{Declarations}

Acknowledgments The authors are grateful to the Malaysian Ministry of Higher Education for Fundamental Research Grant Scheme 2019 (FRGS/1/2018/STG03/USM/02/5) and Universiti Sains Malaysia for supporting this study.

Authors' contributions $\quad \mathrm{HB}$ : Data curation, Investigation, Writing - original draft. KSR: Formal analysis, RB: Formal analysis, VM: Formal analysis, SA: Supervision. CBL: Resources, Supervision. SS: Conceptualisation, Supervision, Writing - review \& editing.

\section{Compliance with ethical standards}

Conflict of interest The authors declare that they have no conflict of interest.

\section{References}

Antony JJJ, Keng CL, Rathinam X, Marimuthu S, Subramaniam S (2011) Effect of preculture and PVS2 incubation conditions followed by histological analysis in the cryopreserved PLBs of Dendrobium Bobby Messina orchid. Aust J Crop Sci 5:1557-1564

Antony JJJ, Zakaria S, Zakaria R, Anak Ujang J, Othman N, Subramaniam S (2019) Biochemical analyses of Dendrobium Sabin Blue PLBs during cryopreservation by vitrification. Physiol Mol Biol Plants 25:1457-1467. https://doi.org/10.1007/s12298-019-00703-2

Ballesteros D, Pence VC (2019) Survival and growth of embryo axes of temperate trees after two decades of cryo-storage. Cryobiology 88:110-113. https://doi.org/10.1016/j.cryobiol.2019.04.005

Bates LS, Waldren RP, Teare ID (1973) Rapid determination of free proline for water-stress studies. Plant Soil 39:205-207

Benson EE (2008) Cryopreservation of phytodiversity: a critical appraisal of theory \& practice. CRC. Crit Rev Plant Sci 27:141-219. https://doi.org/10.1080/07352680802202034

Benson EE, Harding K (2012) Cryopreservation of shoot tips and meristems: an overview of contemporary methodologies. Methods Mol Biol 877:191-226. https://doi.org/10.1007/978-1-61779-818-4_16 
Besi EE, Nikong D, Mustafa M, Go R (2019) Orchid diversity in anthropogenic-induced degraded tropical rainforest, an extrapolation towards conservation. Lankesteriana 19:107-124.

https://doi.org/10.15517/lank.v19i2.38775

Beulé T, Ilbert P, Adeoti K, Durand-Gasselin T, Dumet D, Engelmann F, Morcillo F (2018) Recovery of oil palm (Elaeis guineensis Jacq.) somatic embryos cryostored for 20 years. CryoLett 39:60-66

Bissati S, Boudjenah S, Morisset C, Chenchouni H (2020) Does preculture in sugar-rich media affect carbohydrate content and post-thawing recovery rate of cryopreserved potato (Solanum phureja) shoot tips? J King Saud Univ - Sci 32:1917-1924. https://doi.org/10.1016/j.jksus.2020.01.045

Bradford MM (1976) A rapid and sensitive method for the quantitation of microgram quantities of protein utilising the principle of protein-dye binding. Anal Biochem 72:248-254. https://doi.org/10.1016/00032697(76)90527-3

Bustam BM, Dixon K, Bunn E (2016) A cryopreservation protocol for ex situ conservation of terrestrial orchids using asymbiotic primary and secondary (adventitious) protocorms. In Vitro Cell Dev Biol - Plant 52:185-195. https://doi.org/10.1007/s11627-015-9732-7

Caswell KL, Kartha KK (2009) Recovery of plants from pea and strawberry meristems cryopreserved for 28 years. CryoLett 30:41-46

Chaireok S, Thammasiri K, Meesawat U (2016) Vitrification-based cryopreservation of protocorm-like bodies of an endangered lady's slipper orchid: Paphiopedilum niveum (Rchb.f.) Stein. CryoLett 37:154162

Cheng W, Li H, Zhou F, Zhu B, Yu J, Ding Z (2020) Cryopreservation of Pleione bulbocodioides (Franch.) Rolfe protocorm-like bodies by vitrification. Acta Physiol Plant 42:82. https://doi.org/10.1007/s11738020-03074-4

Christenhusz MJM, Byng JW (2016) The number of known plants species in the world and its annual increase. Phytotaxa 261:201-217. https://doi.org/10.11646/phytotaxa.261.3.1

Chua SP, Normah MN (2011) Effect of preculture, PVS2 and vitamin C on survival of recalcitrant Nephelium ramboutan-ake shoot tips after cryopreservation by vitrification. CryoLett 32:506-515

Chugh S, Guha S, Rao IU (2009) Micropropagation of orchids: a review on the potential of different explants. Sci Hortic 122:507-520. https://doi.org/10.1016/j.scienta.2009.07.016

Coelho N, Gonçalves S, Romano A (2020) Endemic plant species conservation: biotechnological approaches. Plants 9:345. https://doi.org/10.3390/plants9030345

Dar MI, Naikoo MI, Rehman F, Naushin F, Khan FA (2016) Proline accumulation in plants: roles in stress tolerance and plant development. In: Iqbal N, Nazar R, A Khan N (eds) Osmolytes and plants acclimation 
to changing environment: emerging omics technologies. Springer, New Delhi, pp 155-166

Diengdoh RV, Kumaria S, Das MC (2019) Antioxidants and improved regrowth procedure facilitated cryoconservation of Paphiopedilum insigne Wall. Ex. Lindl. - an endangered slipper orchid. Cryobiology 87:60-67. https://doi.org/10.1016/j.cryobiol.2019.02.003

Edesi J, Pirttilä AM, Häggman H (2017) Modified light spectral conditions prior to cryopreservation alter growth characteristics and cryopreservation success of potato (Solanum tuberosum L.) shoot tips in vitro. Plant Cell Tissue Organ Cult 128:409-421. https://doi.org/10.1007/s11240-016-1119-x

Elavarthi S, Martin B (2010) Spectrophotometric assays for antioxidant enzymes in plants. Methods Mol Biol 639:273-281. https://doi.org/10.1007/978-1-60761-702-0_16

Elliott GD, Wang S, Fuller BJ (2017) Cryoprotectants: a review of the actions and applications of cryoprotective solutes that modulate cell recovery from ultra-low temperatures. Cryobiology 76:74-91. https://doi.org/10.1016/j.cryobiol.2017.04.004

Engelmann F (2011) Use of biotechnologies for the conservation of plant biodiversity. In Vitro Cell Dev Biol - Plant 47:5-16. https://doi.org/10.1007/s11627-010-9327-2

Flocco CG, Giulietti AM (2007) In vitro hairy root cultures as a tool for phytoremediation research. In: Willey N (eds) Phytoremediation. Methods in Biotechnology, vol 23. Humana Press, New Jersey, pp 161173

Gale SW, Kumar P, Hinsley A, Cheuk ML, Gao J, Liu H, Liu ZL, Williams SJ (2019) Quantifying the trade in wild-collected ornamental orchids in South China: diversity, volume and value gradients underscore the primacy of supply. Biol Conserv 238:108204. https://doi.org/10.1016/j.biocon.2019.108204

Go R, Besi EE, Dahalan MP, Ahmad R, Ahmadni ASA, Pungga RS (2020) Orchid Conservation Initiatives in Malaysia. Preprints 2020110656. https://doi.org/10.20944/preprints202011.0656.v1

Go R, Ching TM, Nuruddin AA, Abdullah JO, Jin NY, Nordin FA, Eng KH, Nulit R (2015) Extinction risks and conservation status of Corybas (Orchidaceae; Orchidoideae; Diurideae) in Peninsular Malaysia. Phytotaxa 233:273-280. https://doi.org/10.11646/phytotaxa.233.3.4

Go R, Eng KH, Mustafa M, Abdullah JO, Naruddin AA, Lee NS, Lee CS, Eum SM, Park KW, Choi K (2011) An assessment of orchids' diversity in Penang Hill, Penang, Malaysia after 115 years. Biodivers Conserv 20:263-2272. https://doi.org/10.1007/s10531-011-0087-z

Gogoi K, Kumaria S, Tandon P (2013) Cryopreservation of Cymbidium eburneum Lindl. and C. hookerianum Rchb. f., two threatened and vulnerable orchids via encapsulation-dehydration. In Vitro Cell Dev Biol - Plant 49:248-254. https://doi.org/10.1007/s11627-013-9505-0 
González-Arnao MT, Hernández-Ramírez F, Dolce NR, Rascón-Díaz MP, Cruz-Cruz CA (2020)

Cryobiotechnological studies in Vanilla: the orchid of multi-industrial uses. In: Khasim SM, Hegde SN, González-Arnao MT, Thammasiri K (eds) Orchid biology: recent trends \& challenges. Springer, Singapore, pp 21-35

Halder T, Upadhyaya G, Basak C, Das A, Chakraborty C, Ray S (2018) Dehydrins impart protection against oxidative stress in transgenic tobacco plants. Front Plant Sci 9:136 https://doi.org/10.3389/fpls.2018.00136

Harding K, Benson EE (1995) Biochemical and molecular methods for assessing damage, recovery and stability in cryopreserved plant germplasm. In: Grout B (ed) Genetic preservation of plant cells in vitro. Springer, Berlin, pp 113-169

Hayat S, Hayat Q, Alyemeni MN, Wani AS, Pichtel J, Ahmad A (2012) Role of proline under changing environments. Plant Signal Behav 7:1456-1466. https://doi.org/10.4161/psb.21949

Hinsley A, De Boer HJ, Fay MF, Gale SW, Gardiner LM, Gunasekara RS, Kumar P, Masters S, Metusala D, Roberts DL, Veldman S, Wong S, Phelps J (2018) A review of the trade in orchids and its implications for conservation. Bot J Linn Soc 186:435-455. https://doi.org/10.1093/botlinnean/box083

Hirano T, Yukawa T, Miyoshi K, Mii M (2011) Wide applicability of cryopreservation with vitrification method for seeds of some Cymbidium species. Plant Biotechnol 28:99-102. https://doi.org/10.5511/plantbiotechnology.10.1115a

Jitsopakul N, Sangyojarn P, Homchan P, Thammasiri K (2019) Efficiency of aluminum cryo-plates for cryopreservation of Dendrobium signatum Rchb. F. pollinia. Acta Hortic 1234:279-286.

https://doi.org/10.17660/ActaHortic.2019.1234.36

Kaczmarczyk A, Funnekotter B, Menon A, Phang PY, Al-Hanbali A, Bunn E, Mancera RL (2012) Current issues in plant cryopreservation. In: Katkov II (ed) Current frontiers in cryobiology. InTech, Croatia, pp 417-438

Kai H, Iba K (2014) Temperature stress in plants. eLS. John Wiley \& Sons, Chichester. https://doi.org/10.1002/9780470015902.a0001320.pub2

Khor SP, Yeow LC, Poobathy R, Zakaria R, Chew BL, Subramaniam S (2020) Droplet-vitrification of Aranda Broga Blue orchid: role of ascorbic acid on the antioxidant system and genetic fidelity assessments via RAPD and SCoT markers. Biotechnol Reports 26: e00448. https://doi.org/10.1016/j.btre.2020.e00448

Khor SP, Poobathy R, Zakaria R. Subramaniam S (2017) Development of a PVS2 droplet-vitrification cryopreservation technique for Aranda Broga Blue orchid protocorm-like bodies (PLBS). CryoLett 38:290298 
Kim HHH, Lee YGG, Shin DJJ, Ko HCC, Gwag JGG, Cho EGG, Engelmann F (2009) Development of alternative plant vitrification solutions in droplet-vitrification procedures. CryoLett 30:320-334

Kulus D, Zalewska M (2014) Cryopreservation as a tool used in long-term storage of ornamental species - a review. Sci Hortic 168:88-107. https://doi.org/10.1016/j.scienta.2014.01.014

Mohanty P, Das MC, Kumaria S, Tandon P (2012) High-efficiency cryopreservation of the medicinal orchid Dendrobium nobile Lindl. Plant Cell Tissue Organ Cult 109:297-305. https://doi.org/10.1007/s11240011-0095-4

Mohanty P, Das MC, Kumaria S, Tandon P (2013) Cryopreservation of pharmaceutically important orchid Dendrobium chrysanthum Wall. ex Lindl. using vitrification based method. Acta Physiol Plant 35:13731379. https://doi.org/10.1007/s11738-012-1163-z

Møller IM, Jensen PE, Hansson A (2007) Oxidative modifications to cellular components in plants. Annu Rev Plant Biol 58:459-481. https://doi.org/10.1146/annurev.arplant.58.032806.103946

Monnet F, Bordas F, Deluchat V, Baudu M (2006) Toxicity of copper excess on the lichen Dermatocarpon luridum: Antioxidant enzyme activities. Chemosphere 65:1806-1813.

https://doi.org/10.1016/j.chemosphere.2006.04.022

Mubbarakh SA, Rahmah S, Rahman ZA, Sah NNM, Subramaniam S (2014) Cryopreservation of Brassidium Shooting Star Orchid using the PVS3 method supported with preliminary histological analysis. Appl Biochem Biotechnol 172:1131-1145. https://doi.org/10.1007/s12010-013-0597-0

Mubbarakh SA, Udain J, James JJ, Zakaria R, Subramaniam S (2019) Cryopreservation of Rosa hybrida cv. Helmut Schmidt by PVS2 vitrification method using in vitro fragmented explants (IFEs). BioRxiv 567255. https://doi.org/10.1101/567255

Murashige T, Skoog F (1962) A revised medium for rapid growth and bioassays with tobacco tissue cultures. Physiol Plant 15:473-497

Nikishina TV, Popova EV, Vakhrameeva MG, Varlygina TI, Kolomeitseva GL, Burov AV, Popovich EA, Shirokov Al, Shumilov VY, Popov AS (2007) Cryopreservation of seeds and protocorms of rare temperate orchids. Russ J Plant Physiol 54:121-127. https://doi.org/10.1134/S1021443707010189

Ong PT, O’Bryne P, Saw LG, Chung RCK (2017) Checklist of orchids of Peninsular Malaysia. Forest Research Institute Malaysia, Kuala Lumpur. Research Pamphlet. No. 136, pp 169

Panis B, Piette B, Swennen R (2005) Droplet vitrification of apical meristems: a cryopreservation protocol applicable to all Musaceae. Plant Sci 168:45-55. https://doi.org/10.1016/j.plantsci.2004.07.022

Panis B, Nagel M, Van den Houwe I (2020) Challenges and prospects for the conservation of crop genetic resources in field genebanks, in in vitro collections and/or in liquid nitrogen. Plants 9:1634. 
Poobathy R, Nair H, Subramaniam S (2009) Optimisation of encapsulation-dehydration protocol for the orchid hybrid Ascocenda "Princess Mikasa." Adv Environ Biol 3:69-83

Poobathy R, Sinniah UR, Xavier R, Subramaniam S (2013) Catalase and superoxide dismutase activities and the total protein content of protocorm-like bodies of Dendrobium sonia-28 subjected to vitrification. Appl Biochem Biotechnol 170:1066-1079. https://doi.org/10.1007/s12010-013-0241-z

Poobathy R, Zakaria R, Syed Hamzah SM, Subramaniam S (2016) Early studies on protoplast isolation of Ludisia discolor, a wild orchid. Trop Life Sci Res 27:15-19. https://doi.org/10.21315/tlsr2016.27.3.3

Popova E, Kim HH (2019) Development of cryopreservation protocols for endangered wild orchids in Korea. Acta Hortic 1262:43-51. https://doi.org/10.17660/ActaHortic.2019.1262.7

Popova E, Kim HH, Saxena PK, Engelmann F, Pritchard HW (2016) Frozen beauty: the cryobiotechnology of orchid diversity. Biotechnol Adv 34:380-403. https://doi.org/10.1016/j.biotechadv.2016.01.001

Prasongsom S, Thammasiri K, Narangajavana J, Thitamadee S, Chuenboonngarm N, Panvisavas N (2020) Cryopreservation of Dendrobium cruentum Rchb. F. seeds by D cryo-plate and V cryo-plate techniques. Walailak J Sci Technol 17:181-191

Rahmah S, Mubbarakh SA, Khor SP, Subramaniam S (2015) Effects of droplet-vitrification cryopreservation based on physiological and antioxidant enzyme activities of Brassidium Shooting Star orchid. Sci World J 10. https://doi.org/10.1155/2015/961793

Rajasegar A, Mansor A, Poobathy R, Sivalingam E, Sinniah UR, Subramaniam S (2015) An improved PVS2 cryopreservation technique for Ascocenda Wangsa Gold orchid using protocorm-like bodies. Turkish J Biol 39:202-209. https://doi.org/10.3906/biy-1405-7

Reed BM (2017) Plant cryopreservation: a continuing requirement for food and ecosystem security. In Vitro Cell Dev Biol - Plant 53:285-288. https://doi.org/10.1007/s11627-017-9851-4

Rittirat S, Klaocheed S, Suppapan J, Chaithada P, Kalawong S, Thammasiri K (2019) Cryopreservation of an endangered pharmaceutically important orchid, Cymbidium finlaysonianum Lindl. using vitrification technique. Acta Hortic 1234:125-132. https://doi.org/10.17660/ActaHortic.2019.1234.16

Sakai A, Engelmann F (2007) Vitrification, encapsulation-vitrification and droplet-vitrification: a review. CryoLett 28:151-72

Sakai A, Kobayashi S, Oiyama I (1990) Cryopreservation of nucellar cells of navel orange (Citrus sinensis Osb. var. brasiliensis Tanaka) by vitrification. Plant Cell Rep 9:30-33.

https://doi.org/10.1007/BF00232130 
Sakai A, Hirai D, Niino T (2008) Development of PVS-based vitrification and encapsulation-vitrification protocols. In: Reed BM (ed) Plant cryopreservation: a practical guide. Springer, New York, pp 33-57

Sánchez-Rojo S, Cerda-García-Rojas CM, Esparza-García F, Plasencia J, Poggi-Varaldo HM, Ponce-Noyola T, Ramos-Valdivia AC (2015) Long-term response on growth, antioxidant enzymes, and secondary metabolites in salicylic acid pre-treated Uncaria tomentosa microplants. Biotechnol Lett 37:2489-2496. https://doi.org/10.1007/s10529-015-1931-0

Sherif NA, Kumar TS, Rao MV (2016) In vitro regeneration by callus culture of Anoectochilus elatus Lindley, an endangered terrestrial jewel orchid. In Vitro Cell Dev Biol - Plant 52:72-80. https://doi.org/10.1007/s11627-015-9741-6

Shiau YJJ, Nalawade SM, Hsai CNN, Tsay HSS (2005) Propagation of Haemaria discolorvia in vitro seed germination. Biol Plant 49:341-346. https://doi.org/10.1007/s10535-005-0005-x

Soonthornkalump S, Yamamoto SI, Meesawat U (2020) Adding ascorbic acid to reduce oxidative stress during cryopreservation of somatic embryos of Paphiopedilum niveum (Rchb.f.) Stein, an endangered orchid species. Hortic J 89:466-472. https://doi.org/10.2503/hortj.UTD-114

Soshinkova TN, Radyukina NL, Korolkova DV, Nosov AV (2013) Proline and functioning of the antioxidant system in Thellungiella salsuginea plants and cultured cells subjected to oxidative stress. Russ J Plant Physiol 60:41-54. https://doi.org/10.1134/S1021443713010093

Stachura SS, Malajczuk CJ, Mancera RL (2019) Does sucrose change its mechanism of stabilisation of lipid bilayers during desiccation? Influences of hydration and concentration. Langmuir 35:15389-15400. https://doi.org/10.1021/acs.langmuir.9b03086

Steponkus PL, Lanphear FO (1967) Refinement of the triphenyl tetrazolium chloride method of determining cold injury. Plant Physiol 42:1423-1426

Suzuki N, Mittler R (2006) Reactive oxygen species and temperature stresses: a delicate balance between signalling and destruction. Physiol Plant 126:45-51. https://doi.org/10.1111/j.0031-9317.2005.00582.x

Suzuki N, Koussevitzky S, Mittler R, Miller G (2012) ROS and redox signalling in the response of plants to abiotic stress. Plant Cell Environ 35:259-270. https://doi.org/10.1111/j.1365-3040.2011.02336.x

Swarts ND, Dixon KW (2009) Terrestrial orchid conservation in the age of extinction. Ann Bot 104:543556. https://doi.org/10.1093/aob/mcp025

Teixeira da Silva JA (2013) Cryopreservation of hybrid Cymbidium protocorm-like bodies by encapsulation-dehydration and vitrification. In Vitro Cell Dev Biol - Plant 49:690-698. https://doi.org/10.1007/s11627-013-9550-8 
Teoh ES (2019) Medicinal orchids in the Malay Archipelago. In: Teoh ES (ed) Orchids as aphrodisiac, medicine or food. Springer, Cham, pp 255-289

Towill LE, Bonnart R (2003) Cracking in a vitrification solution during cooling or warming does not affect growth of cryopreserved mint shoot tips. CryoLett 24:341-346

Uchendu EE, Leonard SW, Traber MG, Reed BM (2010) Vitamins C and E improve regrowth and reduce lipid peroxidation of blackberry shoot tips following cryopreservation. Plant Cell Rep 29:25-35. https://doi.org/10.1007/s00299-009-0795-y

Uchendu EE, Shukla MR, Reed BM, Saxena PK (2013) Melatonin enhances the recovery of cryopreserved shoot tips of American elm (Ulmus americana L.). J Pineal Res 55:435-442. https://doi.org/10.1111/jpi.12094

Uchendu EE, Shukla MR, Reed BM, Saxena PK (2014) An efficient method for cryopreservation of St John's wort and tobacco: role of melatonin. Acta Hortic 1039:233-242

Verleysen H, Samyn G, Van Bockstaele E, Debergh P (2004) Evaluation of analytical techniques to predict viability after cryopreservation. Plant Cell Tissue Organ Cult 77:11-21. https://doi.org/10.1023/B:TICU.0000016483.00158.a9

Vianna MG, Garcia RO, Mansur E, Engelmann F, Pacheco G (2019) Oxidative stress during the cryopreservation of Passiflora suberosa L. shoot tips using the V-Cryo-plate technique: determination of the critical stages of the protocol. Plant Cell Tissue Organ Cult 139:369-379.

https://doi.org/10.1007/s11240-019-01690-8

Volk GM, Henk AD, Bonnart RM, Shepherd A, Gross BL (2014) Plant shoot tip response to treatment with Plant Vitrification Solution \#2. Acta Hortic 1039:81-84. https://doi.org/10.17660/ActaHortic.2014.1039.8

Volkova LA, Urmantseva VV, Popova EV, Nosov AM (2015) Physiological, cytological and biochemical stability of Medicago sativa L. cell culture after 27 years of cryogenic storage. CryoLett 36:252-63

Wang MR, Lambardi M, Engelmann F, Pathirana R, Panis B, Volk GM, Wang QC (2020) Advances in cryopreservation of in vitro-derived propagules: technologies and explant sources. Plant Cell Tissue Organ Cult. 144:7-20. https://doi.org/10.1007/s11240-020-01770-0

Wesley-Smith J, Berjak P, Pammenter NW, Walters C (2014) Intracellular ice and cell survival in cryoexposed embryonic axes of recalcitrant seeds of Acer saccharinum: an ultrastructural study of factors affecting cell and ice structures. Ann Bot 113:695-709. https://doi.org/10.1093/aob/mct284

Zhang A, Wang H, Shao Q, Xu M, Zhang W, Li M (2015) Large scale in vitro propagation of Anoectochilus roxburghii for commercial application: pharmaceutically important and ornamental plant. Ind Crops Prod 70:158-162. https://doi.org/10.1016/j.indcrop.2015.03.032 
Zhang S, Yang Y, Li J, Qin J, Zhang W, Huang W, Hu H (2018) Physiological diversity of orchids. Plant Divers 40:196-208. https://doi.org/10.1016/j.pld.2018.06.003

\section{Figures}
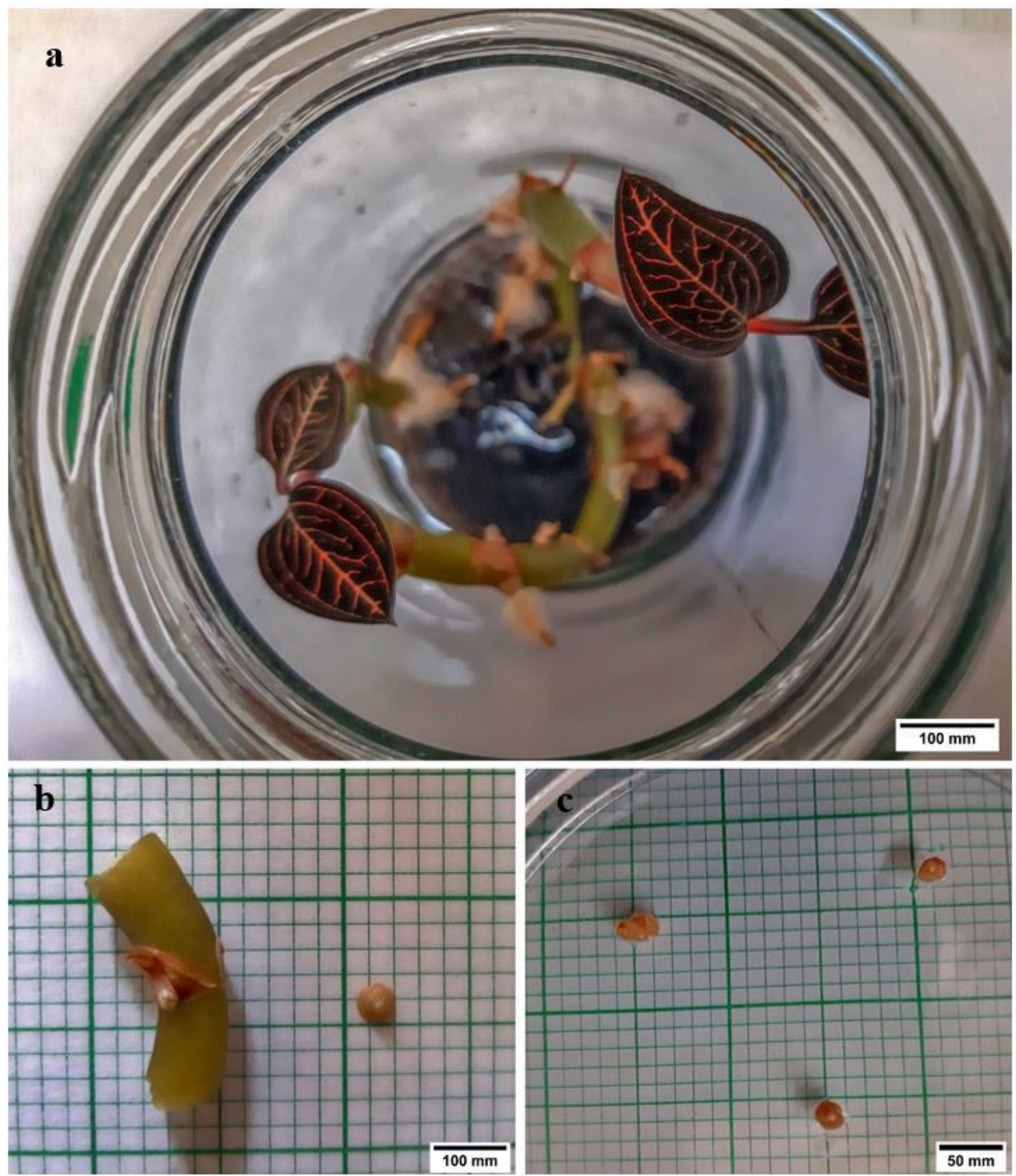

Figure 1 
a An in vitro stock culture of Ludisia discolor, b 12-weeks old nodal segment (left) and excised axillary bud (4 - $5 \mathrm{~mm}$ in size) (right), c Cryopreserved meristem observed after 4-week of growth recovery.
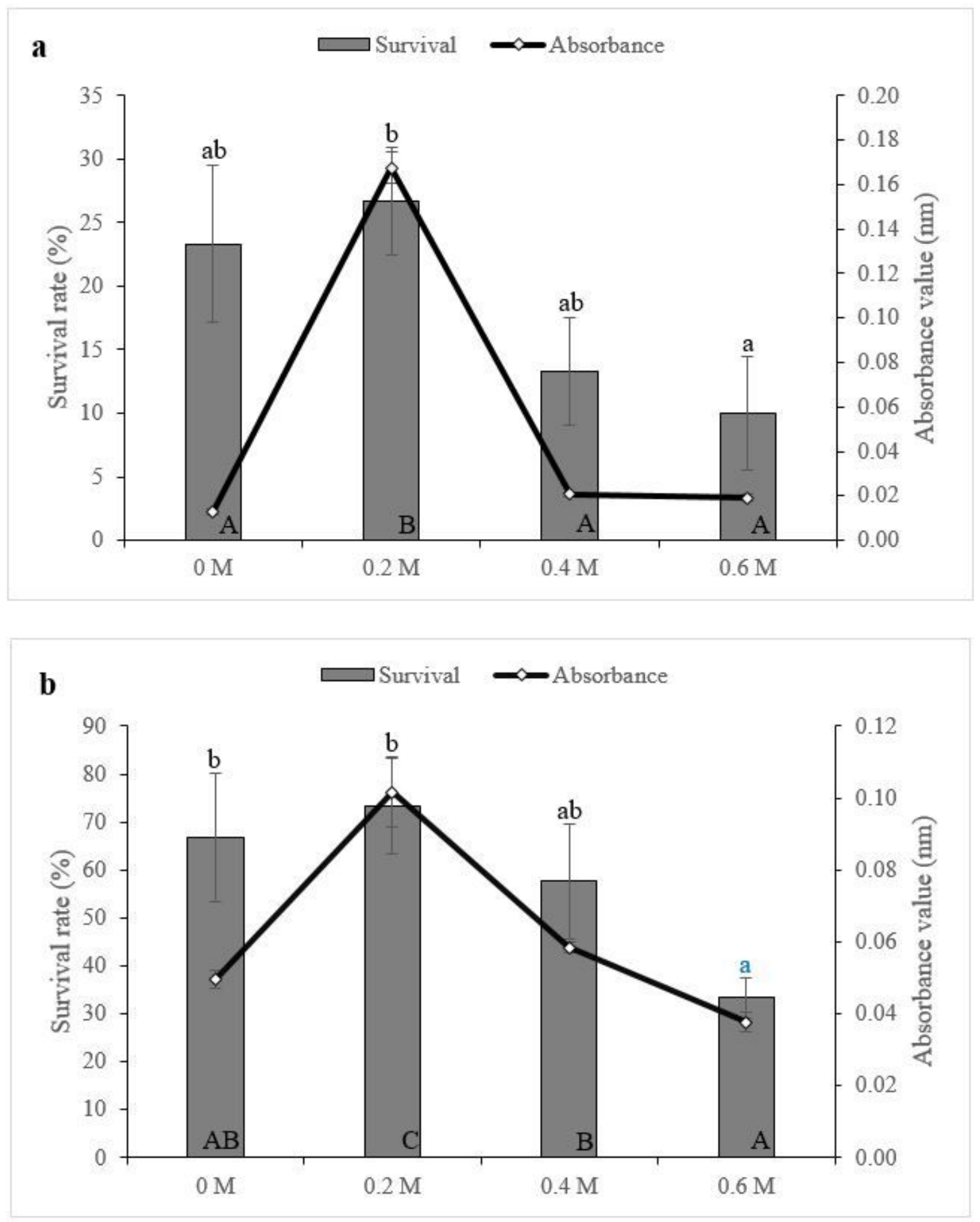

Figure 2

Effect of sucrose concentration during preculture on the viability of a cryopreserved (+LN) and b noncryopreserved (-LN) axillary meristems before dehydration and LN immersion. Error bars represent 
standard errors. Means with different letters (upper case: Absorbance; lower case: Survival) are significantly different based on Duncan Multiple Range Test (DMRT) at $p \leq 0.05$.

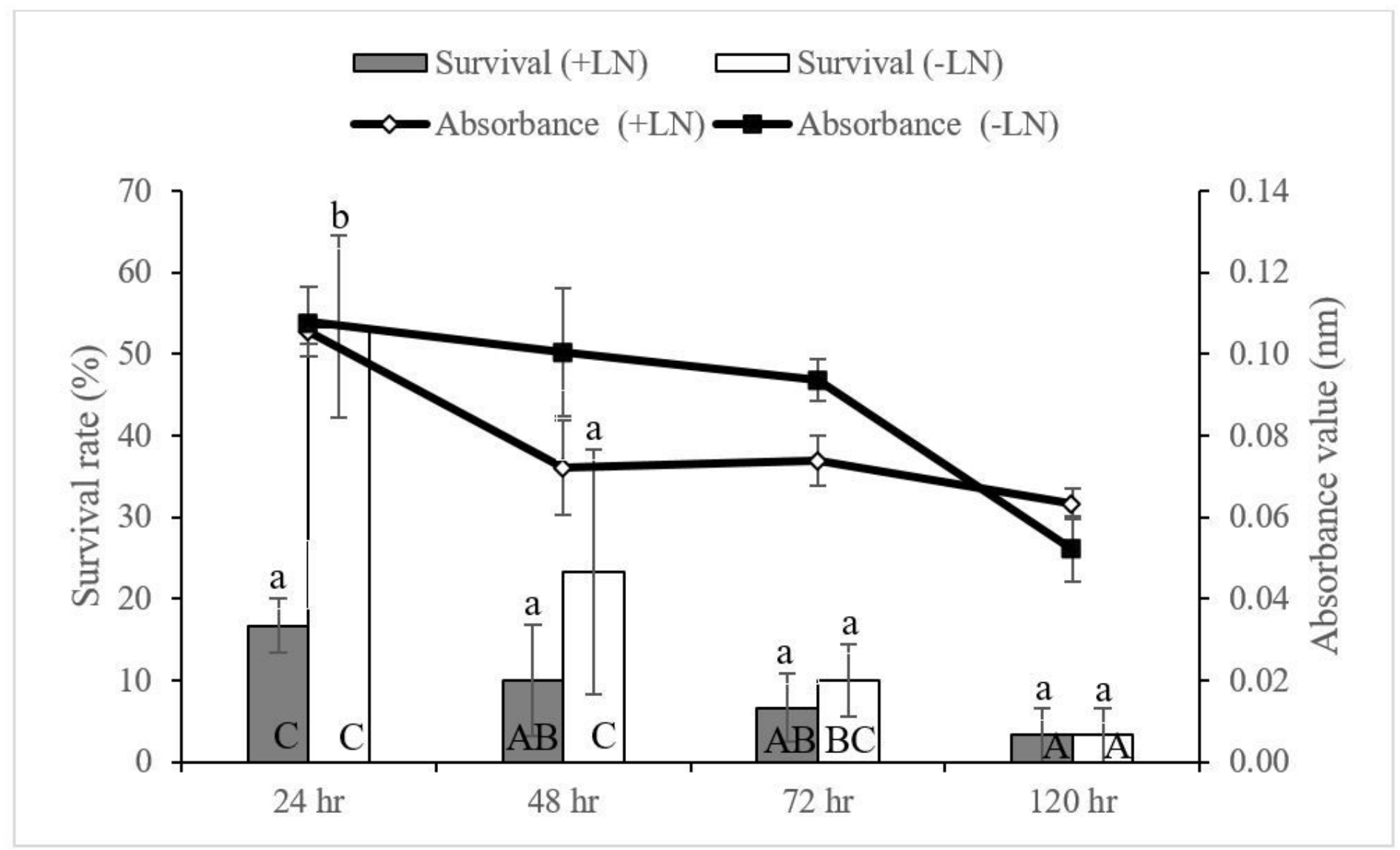

Figure 3

Effect of preculture duration on the viability of cryopreserved (+LN) and non-cryopreserved (-LN) axillary meristems before dehydration and LN immersion. Error bars represent standard errors. Means with different letters (upper case: Absorbance; lower case: Survival) are significantly different based on Duncan Multiple Range Test (DMRT) at $\mathrm{p} \leq 0.05$. 

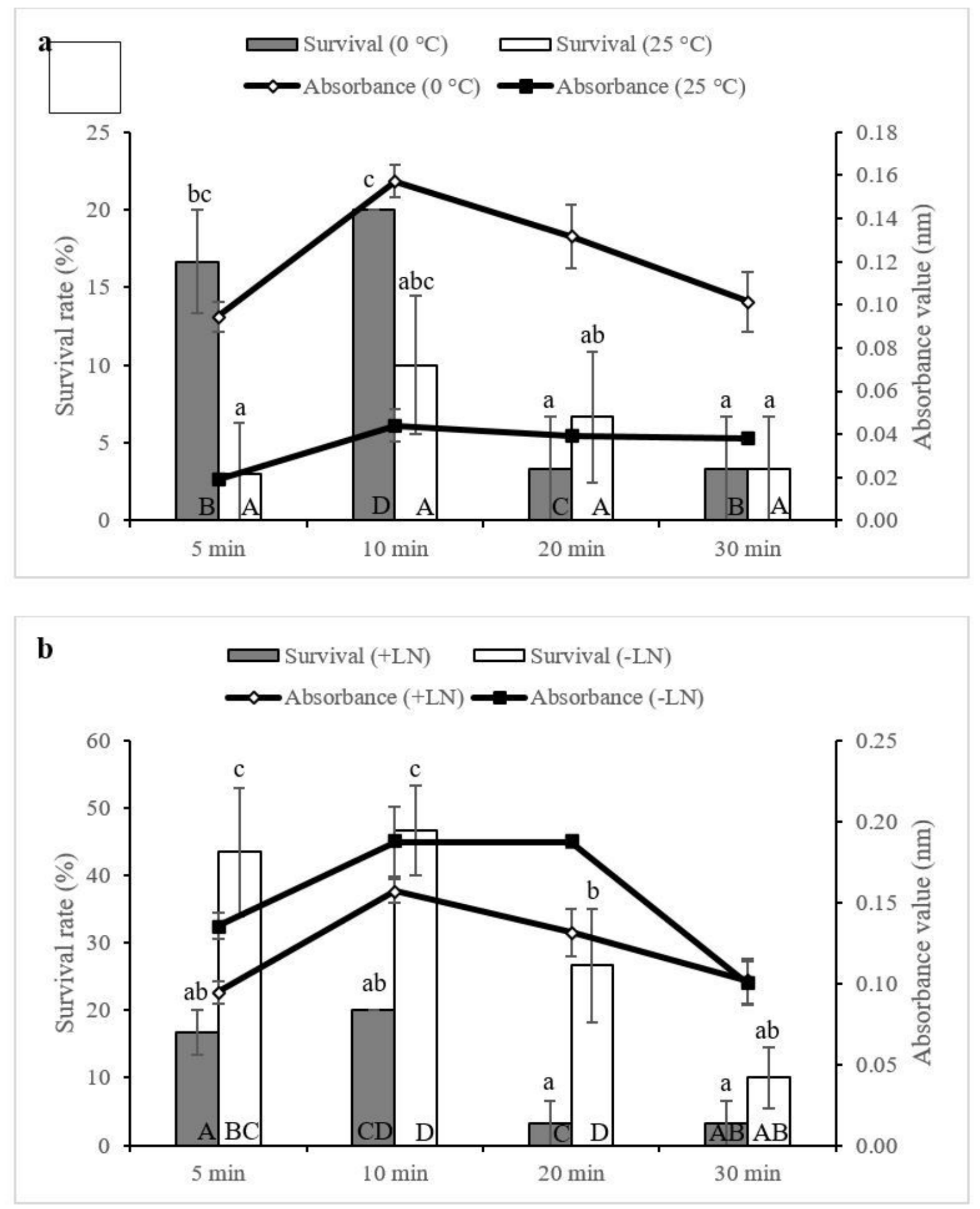

\section{Figure 4}

Effect of PVS2 dehydration duration on the viability of a cryopreserved $(+L N)$ axillary meristems at $0{ }^{\circ} \mathrm{C}$ and $25^{\circ} \mathrm{C}$ and $\mathrm{b}$ cryopreserved $(+\mathrm{LN})$ and non-cryopreserved (-LN) axillary meristems at $0{ }^{\circ} \mathrm{C}$. Error bars represent standard errors. Means with different letters (upper case: Absorbance; lower case: Survival) are significantly different based on Duncan Multiple Range Test (DMRT) at $p \leq 0.05$. 
a $\rightleftarrows$ Survival $\leadsto$ Absorbance

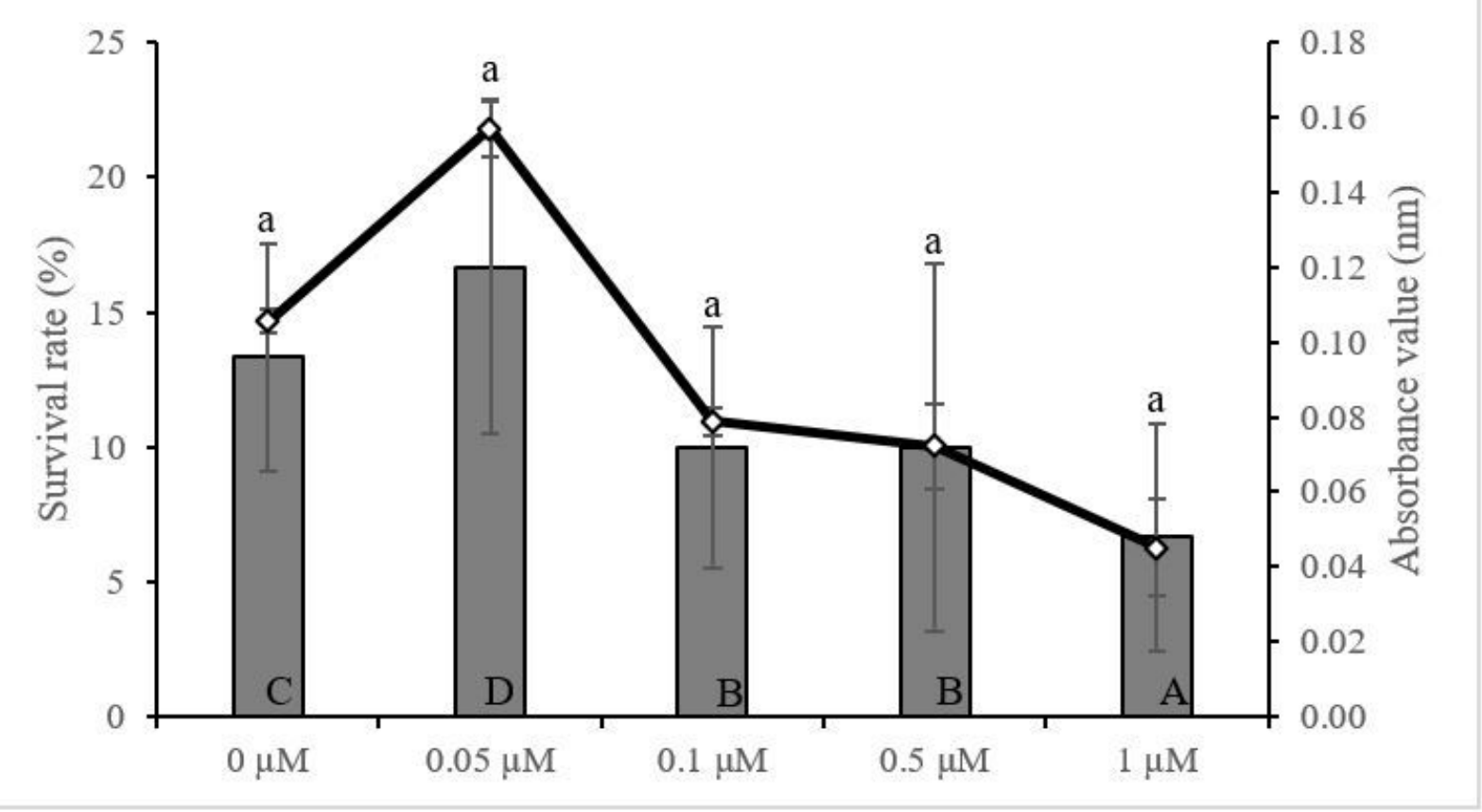

b
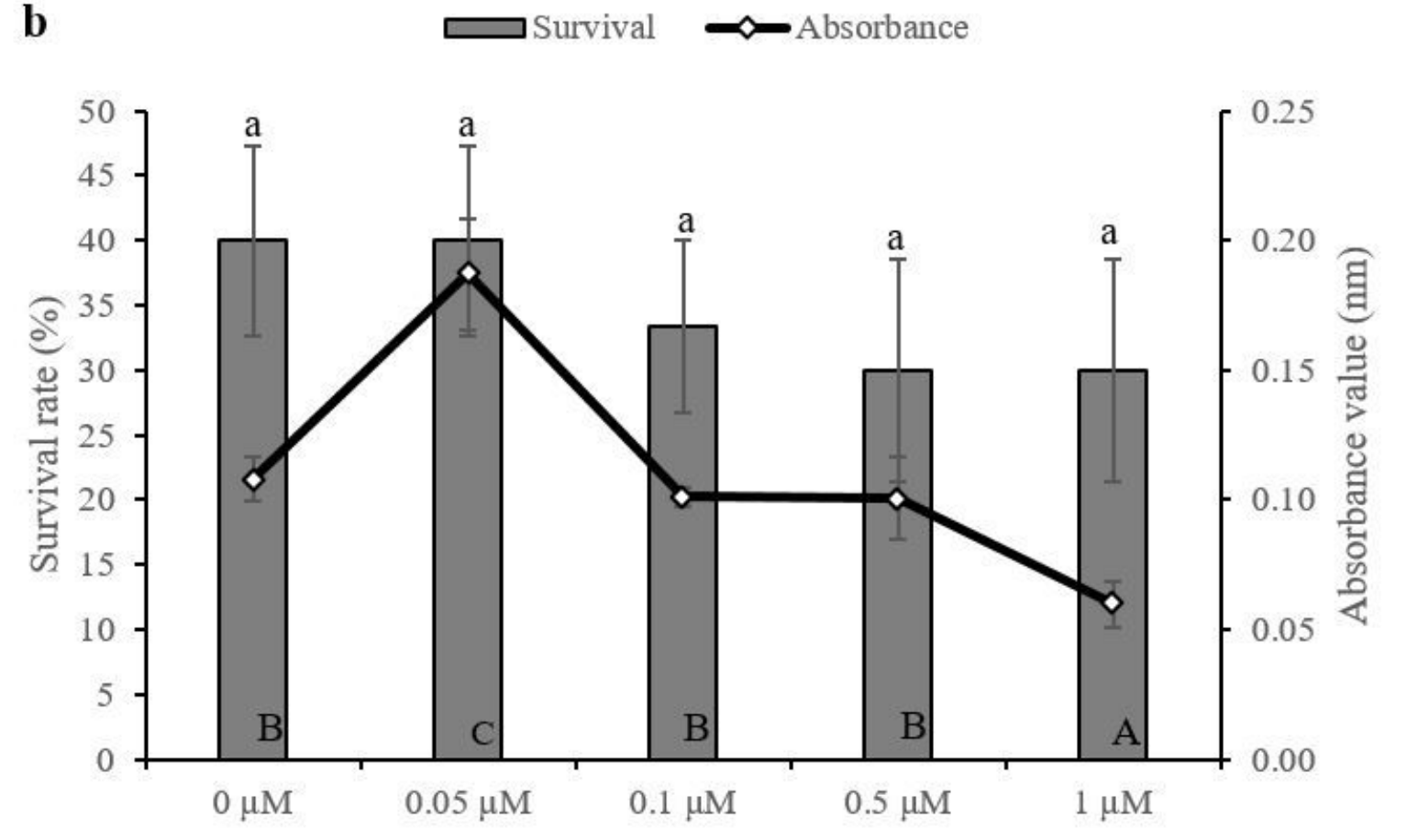

Figure 5

Effect of exogenous melatonin concentration on the viability of a cryopreserved $(+L N)$ and $b$ noncryopreserved (-LN) axillary meristems during the growth recovery stage. Error bars represent standard errors. Means with different letters (upper case: Absorbance; lower case: Survival) are significantly different based on Duncan Multiple Range Test (DMRT) at $p \leq 0.05$. 


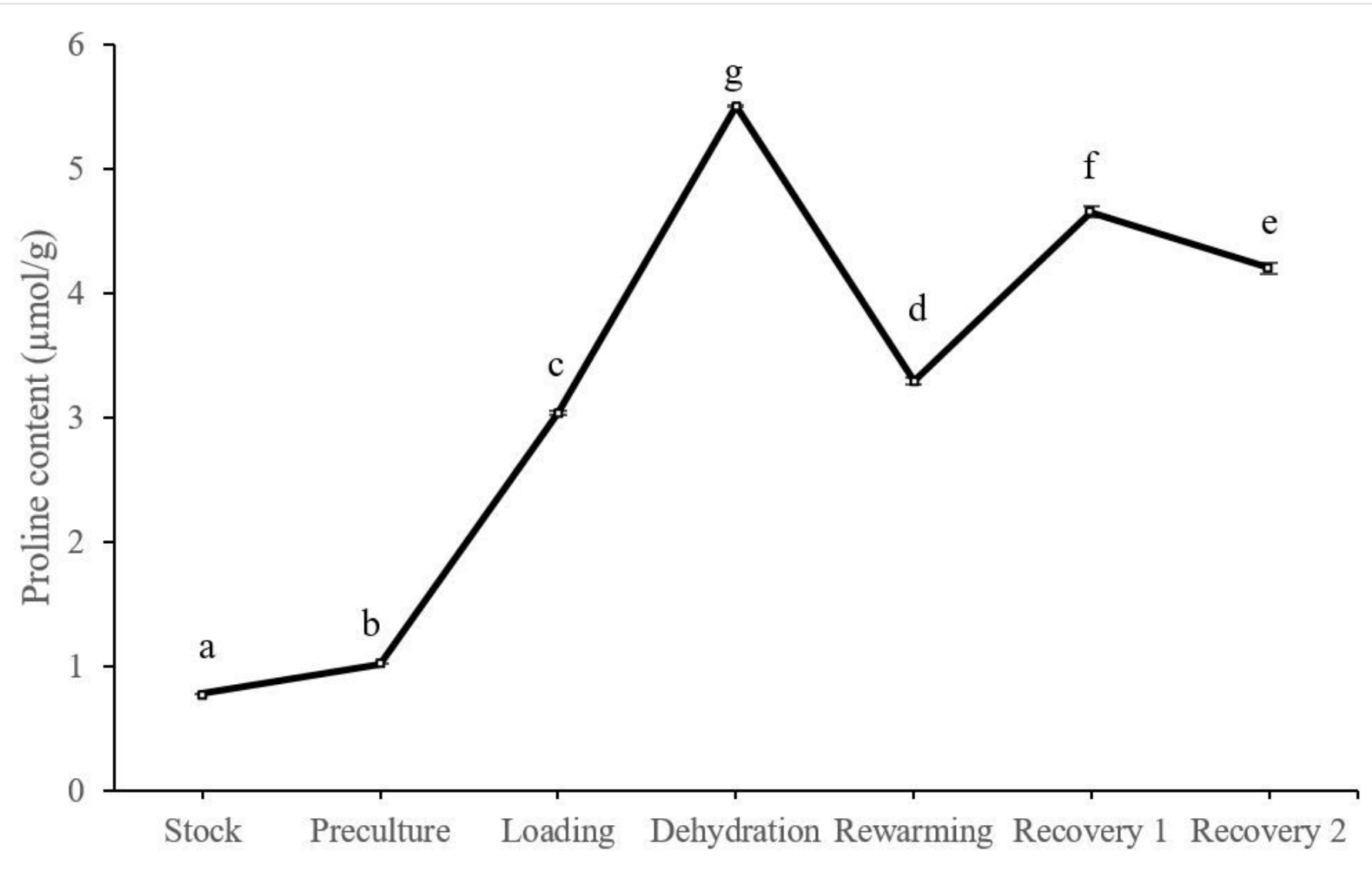

\section{Figure 6}

Proline content of cryopreserved axillary meristems at different stages in cryopreservation. Error bars represent standard errors. Means with different letters are significantly different based on Duncan Multiple Range Test (DMRT) at $p \leq 0.05$. 


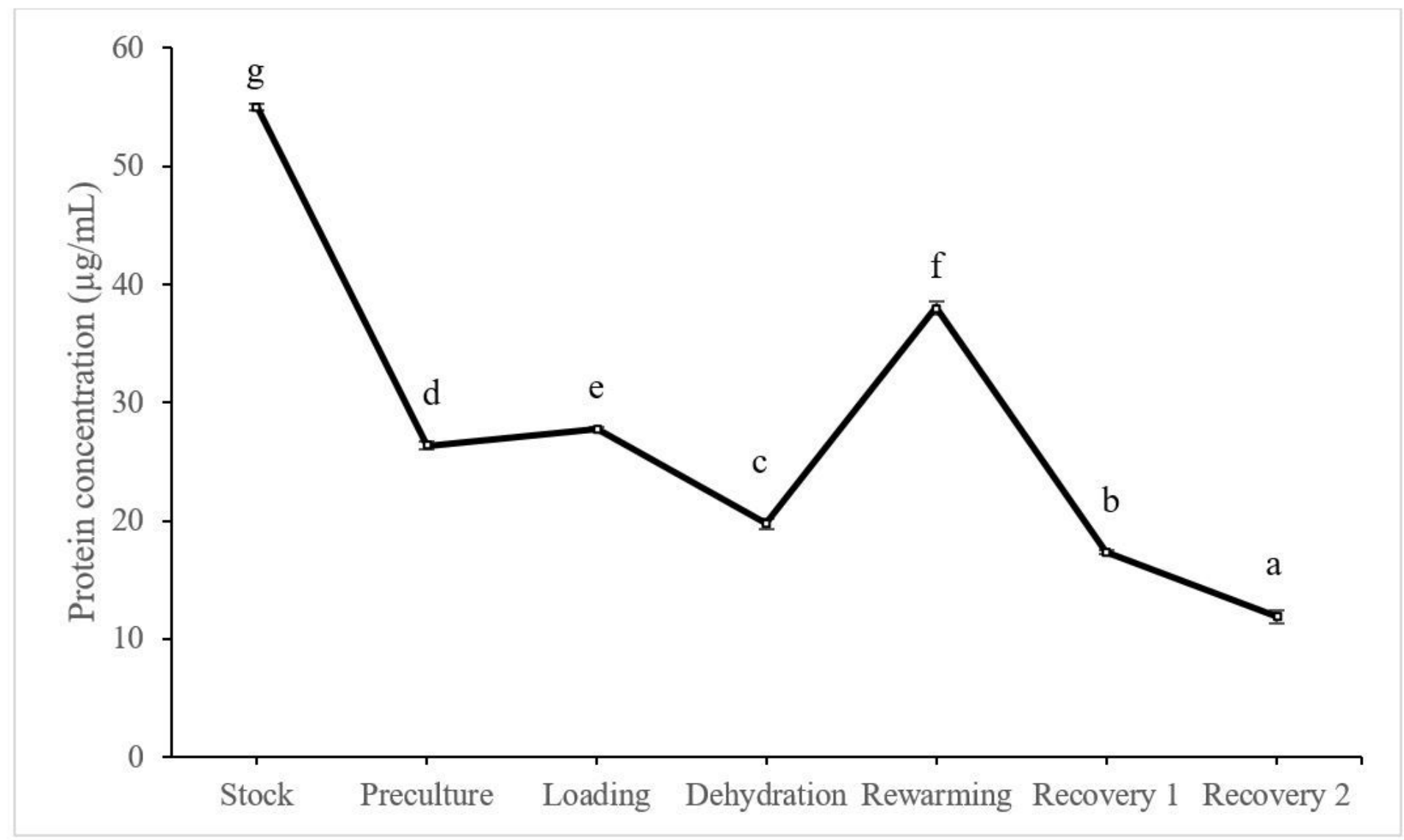

\section{Figure 7}

Total soluble protein content of cryopreserved axillary meristems at different stages in cryopreservation. Error bars represent standard errors. Means with different letters are significantly different based on Duncan Multiple Range Test (DMRT) at $\mathrm{p} \leq 0.05$. 


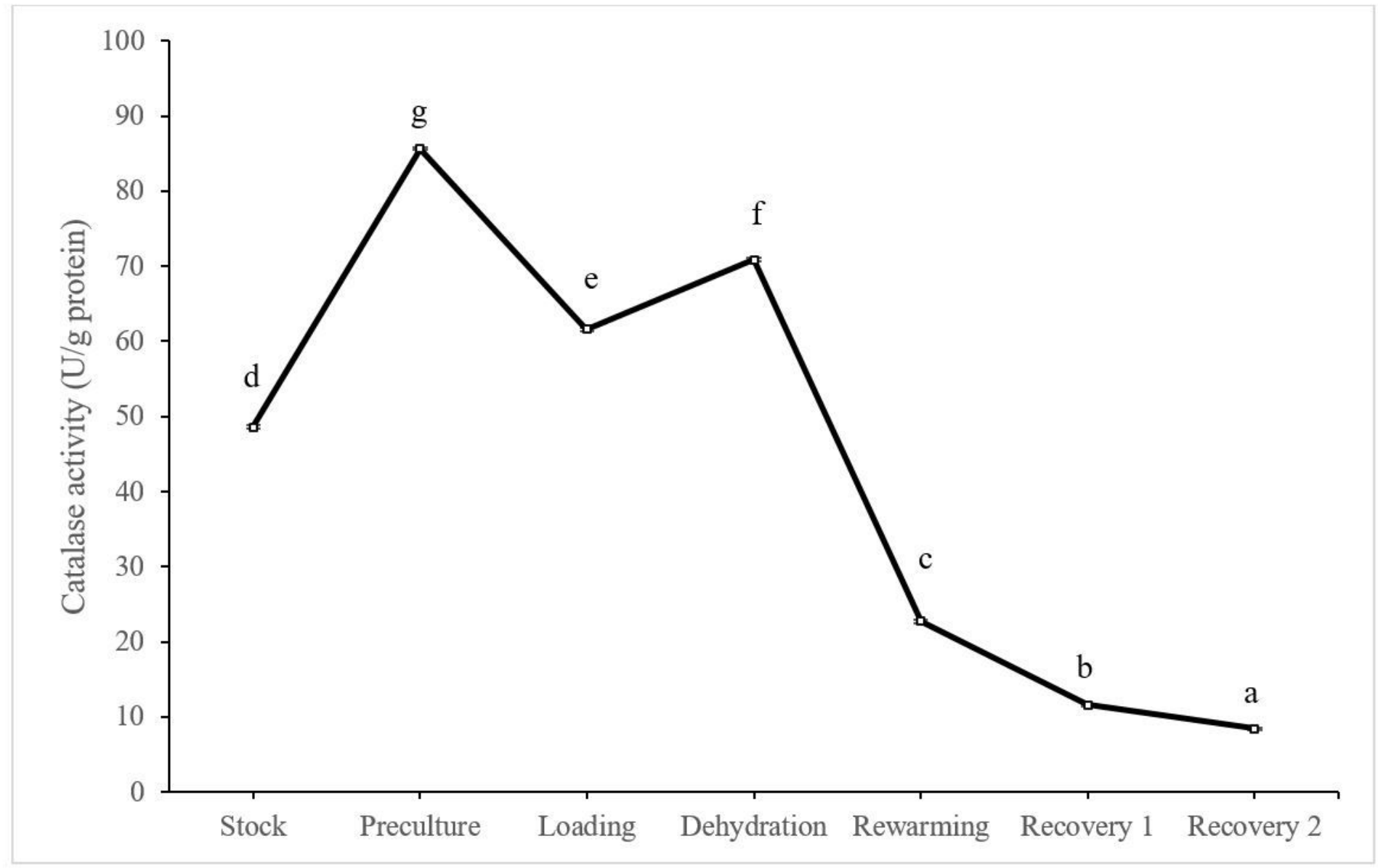

\section{Figure 8}

Catalase activities of cryopreserved axillary meristems at different stages in cryopreservation. Error bars represent standard errors. Means with different letters are significantly different based on Duncan Multiple Range Test (DMRT) at $\mathrm{p} \leq 0.05$. 


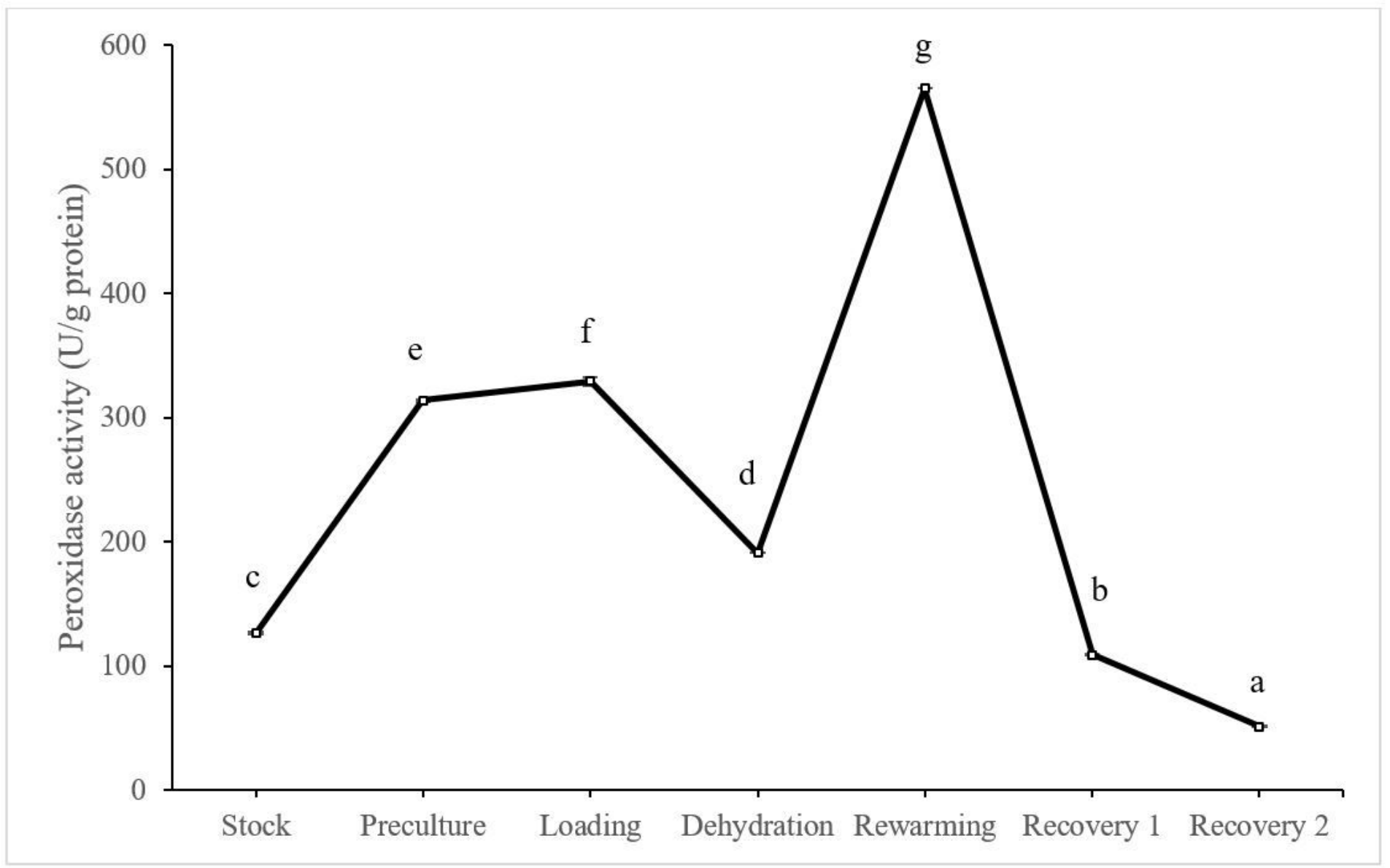

Figure 9

Peroxidase activities of cryopreserved axillary meristems at different stages in cryopreservation. Error bars represent standard errors. Means with different letters are significantly different based on Duncan Multiple Range Test (DMRT) at $\mathrm{p} \leq 0.05$. 


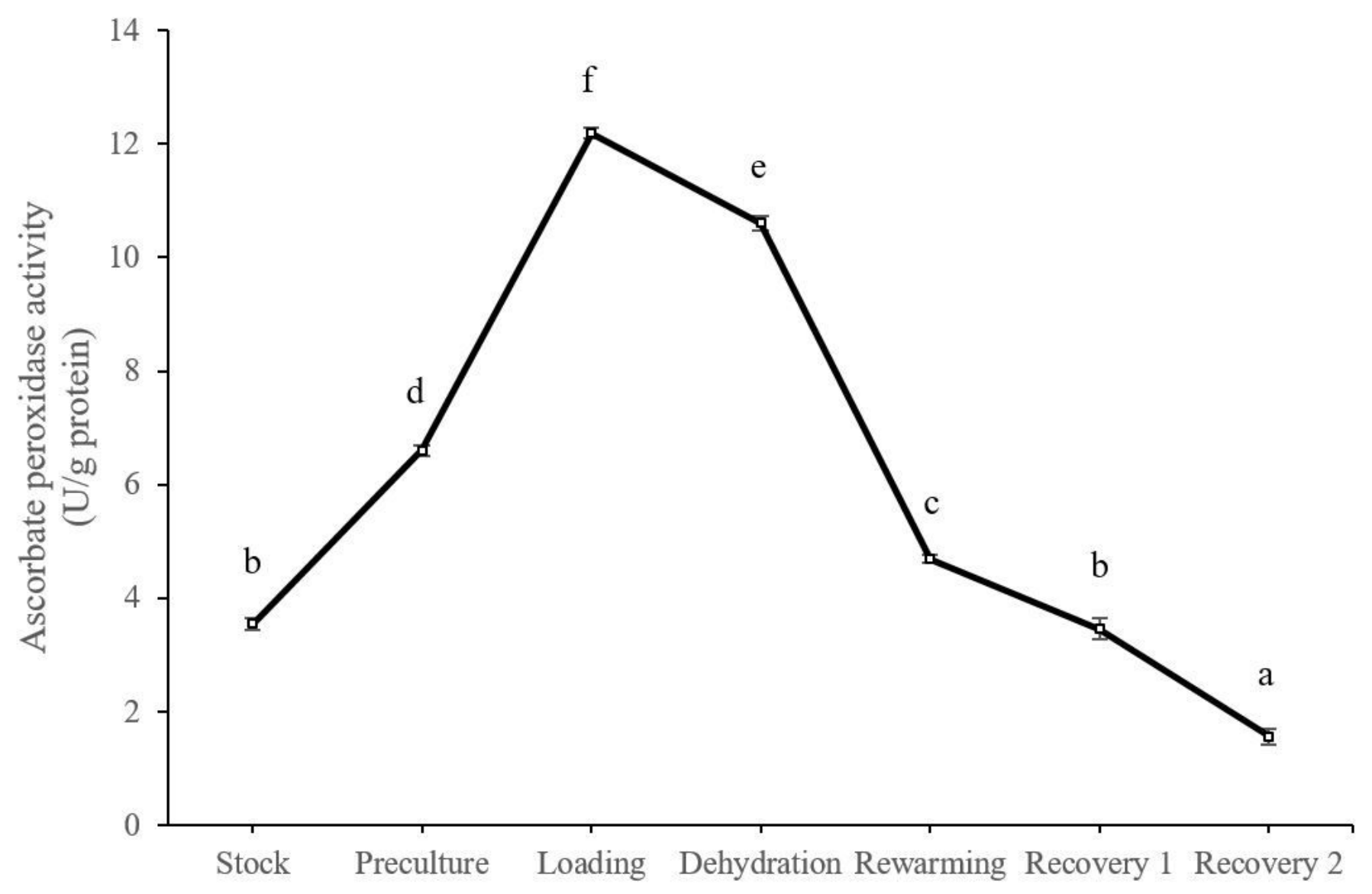

Figure 10

Ascorbate peroxidase activities of cryopreserved axillary meristems at different stages in cryopreservation. Error bars represent standard errors. Means with different letters significantly different based on Duncan Multiple Range Test (DMRT) at $p \leq 0.05$. 